\title{
Impacts of Water Quality on Residential Water Heating Equipment
}

SH Widder

MC Baechler

November 2013

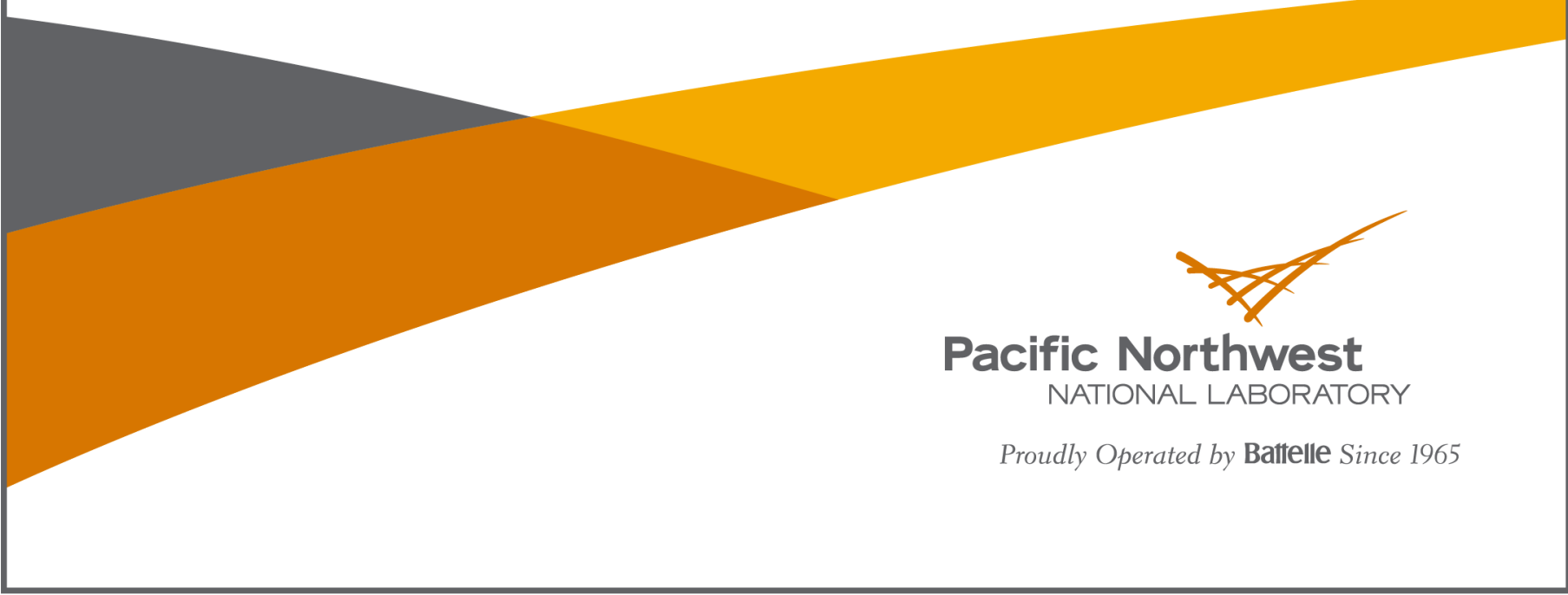




\title{
DISCLAIMER
}

This report was prepared as an account of work sponsored by an agency of the United States Government. Neither the United States Government nor any agency thereof, nor Battelle Memorial Institute, nor any of their employees, makes any warranty, express or implied, or assumes any legal liability or responsibility for the accuracy, completeness, or usefulness of any information, apparatus, product, or process disclosed, or represents that its use would not infringe privately owned rights. Reference herein to any specific commercial product, process, or service by trade name, trademark, manufacturer, or otherwise does not necessarily constitute or imply its endorsement, recommendation, or favoring by the United States Government or any agency thereof, or Battelle Memorial Institute. The views and opinions of authors expressed herein do not necessarily state or reflect those of the United States Government or any agency thereof.

\author{
PACIFIC NORTHWEST NATIONAL LABORATORY \\ operated by \\ BATTELLE \\ for the \\ UNITED STATES DEPARTMENT OF ENERGY \\ under Contract DE-AC05-76RL01830
}

Printed in the United States of America
Available to DOE and DOE contractors from the Office of Scientific and Technical Information,
P.O. Box 62, Oak Ridge, TN 37831-0062;
ph: (865) 576-8401
fax: $(865)$ 576-5728
email: reports@adonis.osti.gov

Available to the public from the National Technical Information Service

5301 Shawnee Rd., Alexandria, VA 22312

ph: (800) 553-NTIS (6847)

email: orders $\omega$ ntis.gov $<$ http://www.ntis.gov/about/form.aspx $>$

Online ordering: http://www.ntis.gov 


\section{Impacts of Water Quality on Residential Water Heating Equipment}

SH Widder

MC Baechler

November 2013

Prepared for

the U.S. Department of Energy

under Contract DE-AC05-76RL01830

Pacific Northwest National Laboratory

Richland, Washington 99352 

PNNL-22921

\section{Summary}

Water heating is a ubiquitous energy use in residential housing, accounting for 17.7 percent of residential energy use (EIA 2012). Today, many efficient water heating options are available for every fuel type, from electric and gas to more unconventional fuel types such as propane, solar, and fuel oil. The best water heating option for a given household will depend on a number of factors, including average daily hot water use (total gallons per day), hot water draw patterns (close together or spread out), the hot water distribution system (compact or distributed), installation constraints (such as space, electrical service, or venting accommodations), and fuel-type availability and cost.

While in general more efficient water heaters are more expensive than conventional water heating technologies, the savings in energy use, and thus utility bills, can recoup the additional up-front investment and make an efficient water heater a good investment over time in most situations, although the specific payback period for a given operating water heater will vary widely. However, the expected lifetime of a water heater in a given installation can dramatically influence the cost-effectiveness and savings potential of a water heater and should be considered, along with water use characteristics, fuel availability and cost, and specific home characteristics, when selecting the optimum water heating equipment for a particular installation. Thus, when determining the appropriate selection and application of water heating equipment, especially when determining the cost-effectiveness of more expensive, highefficiency equipment options, the lifetime of equipment is very important.

The local water quality is one of the factors that contributes most significantly to the long-term performance and longevity of water heating equipment. Specifically, highly alkaline water will lead to the accumulation of scale, which will impact the efficiency of tankless and gas storage water heaters and can lead to decreased equipment life. Conversely, soft water increases the risk of corrosion, which can decrease equipment life by more than half if not properly mitigated. Increasing the lifetime of water heaters can improve the cost-effectiveness and increase the amount of savings achieved by an efficient water heater investment. Based on the specific water quality characteristics in a given location, different water heater design parameters and maintenance requirements can be applied to mitigate scale accumulation and corrosion in hard and soft waters, respectively. These approaches are summarized in Table S1.

Additional investigation is needed regarding the long-term performance of tankless water heaters in soft water conditions and alternative water softening solutions that mitigate highly corrosive water.

These results should be shared with homeowners and builders via online web applications and tools to aid in choosing the most appropriate water heating technology for a given situation and recommending preventative maintenance. It is important that water quality and long-term performance impacts are considered in cost-effectiveness and life-cycle cost analyses to make sure consumers, utilities, and the nation achieve the energy savings expected over the lifetime of the product. 

Table S.1. Summary of Impacts and Mitigation Measures for Effects of Hard Water and Soft Water on Water Heaters

\begin{tabular}{|c|c|c|c|c|}
\hline \multirow[b]{2}{*}{$\begin{array}{c}\text { Water Heater } \\
\text { Type }\end{array}$} & \multicolumn{2}{|r|}{ Hard Water } & \multicolumn{2}{|c|}{ Soft Water } \\
\hline & Impact & Mitigation & Impact & Mitigation \\
\hline Electric Storage & $\begin{array}{l}\text { Efficiency }=\text { negligible } \\
\underline{\text { Lifetime }}=\text { minimal until } \\
\text { sediment covers bottom } \\
\text { element (rare). }\end{array}$ & $\begin{array}{l}\text { - Install curved dip tube } \\
\text { - Regularly (every year) drain tank to } \\
\text { remove sediment and delime as } \\
\text { necessary } \\
\text { - Reduce tank temp and reduce water } \\
\text { use } \\
\text { - Install lower watt-density elements }\end{array}$ & $\begin{array}{l}\text { Efficiency }=\text { none. } \\
\text { Lifetime }=\text { up to } 50-60 \% \\
\text { reduction in expected } \\
\text { lifetime, based on water } \\
\text { quality and maintenance } \\
\text { practices for glass-lined steel } \\
\text { tanks }\end{array}$ & $\begin{array}{l}\text { - Purchase a tank made of } \\
\text { noncorroding material } \\
\text { - Inspect anode rod every } 1-2 \\
\text { years and replace as necessary or } \\
\text { use powered anode } \\
\text { - Consider installing second anode } \\
\text { rod } \\
\text { - Reduce tank temp and reduce } \\
\text { water use }\end{array}$ \\
\hline Gas Storage & $\begin{array}{l}\text { Efficiency }=\text { negligible } \\
\text { Lifetime }=\text { minimal until } \\
\text { sediment covers bottom } \\
\text { element (rare). }\end{array}$ & $\begin{array}{l}\text { - Install curved dip tube } \\
\text { - Regularly (every year) drain tank to } \\
\text { remove sediment and delime as } \\
\text { necessary } \\
\text { - Reduce tank temp and reduce water } \\
\text { use } \\
\text { - Soften water (with appropriate anode } \\
\text { protection) }\end{array}$ & $\begin{array}{l}\text { Efficiency }=\text { none } \\
\text { Lifetime }=\text { minimal until } \\
\text { sediment covers bottom } \\
\text { element (rare) }\end{array}$ & $\begin{array}{l}\text { - Purchase a tank made of } \\
\text { noncorroding material } \\
\text { - Inspect anode rod every } 1-2 \\
\text { years and replace as necessary or } \\
\text { use powered anode } \\
\text { - Consider installing second anode } \\
\text { rod } \\
\text { - Reduce tank temp and reduce } \\
\text { water use }\end{array}$ \\
\hline
\end{tabular}

\begin{tabular}{l|l} 
Gas and & Efficiency $=$ negligible \\
Electric \\
Tankless
\end{tabular}$\quad \begin{aligned} & \text { Lifetime }=\text { minimal until } \\
& \text { sediment covers bottom } \\
& \text { element (rare). }\end{aligned}$

- Regularly delime equipment as recommended by manufacturer

- Reduce temp setpoint and reduce water use

- Soften water

\section{Efficiency $=$ none}

$\underline{\text { Lifetime }}=$ reduced due to use

of less active metals in

materials of construction*

$*=$ more research needed to verify recommendation. 



\section{Acknowledgments}

The authors acknowledge the guidance and support of Eric Werling and Sam Rashkin of the U.S. Department of Energy Building Technologies Program in sponsoring this work. The team is most appreciative of GE Appliances and Bonneville Power Administration, who are also partners in this work. The authors are also indebted to Mary Frances Lembo and Marye Hefty who provided excellent background information, technical review, and feedback on this work. Finally, this work is dedicated to Todd Samuel, the technical group manager for Pacific Northwest National Laboratory's (PNNL's) Energy Policy and Economics group for his unwavering support of his staff, the PNNL Lab Homes, and this project. 



\section{Acronyms and Abbreviations}

$\begin{array}{ll}\mathrm{Al} & \text { aluminum } \\ \mathrm{Al} / \mathrm{Zn} & \text { aluminum/zinc } \\ \mathrm{CaCO}_{3} & \text { calcium carbonate } \\ \mathrm{Mg} & \text { magnesium } \\ \mathrm{mg} / \mathrm{L} & \text { milligrams per liter } \\ \mathrm{Na} & \text { sodium } \\ \mathrm{TDS} & \text { total dissolved solids }\end{array}$





\section{Contents}

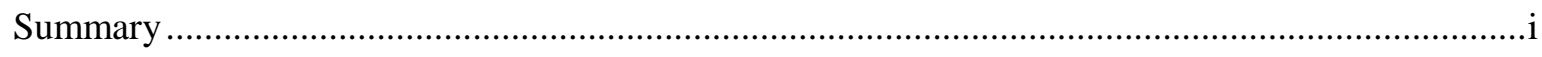

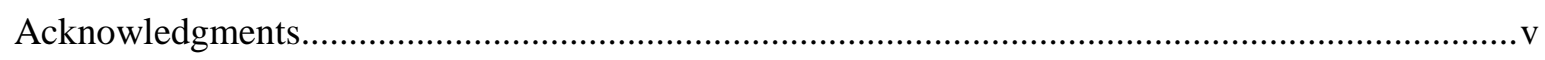

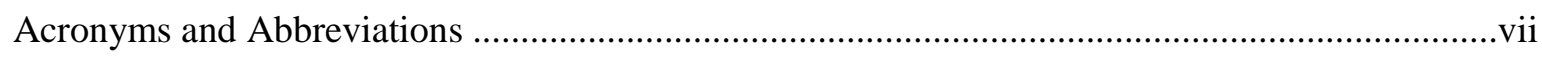

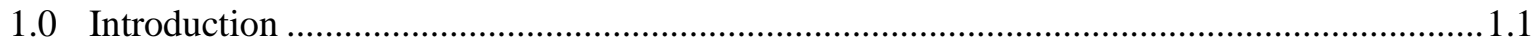

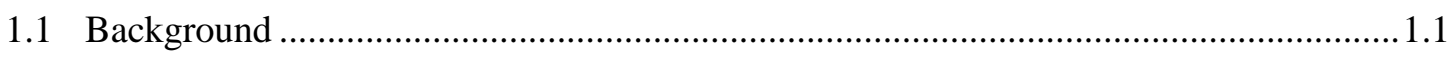

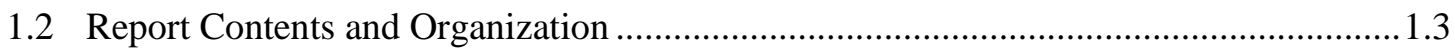

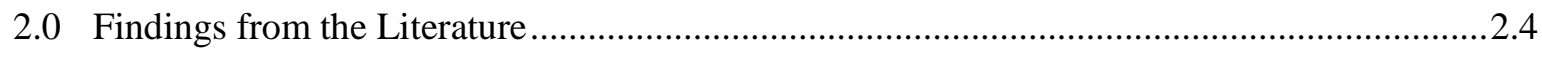

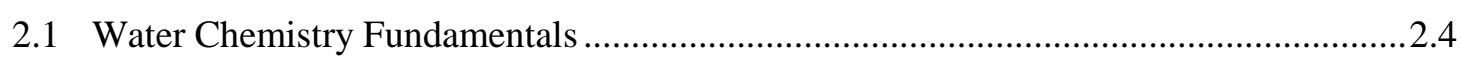

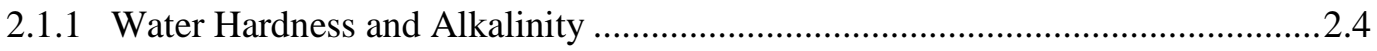

2.1.2 Water Quality in the United States................................................................. 2.6

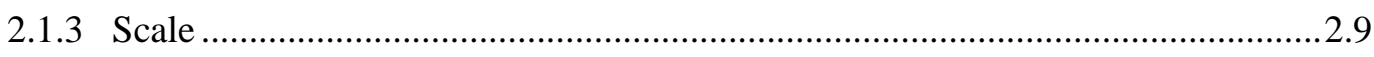

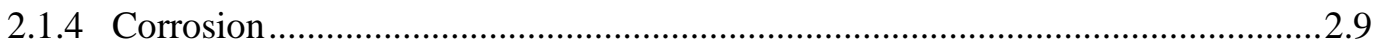

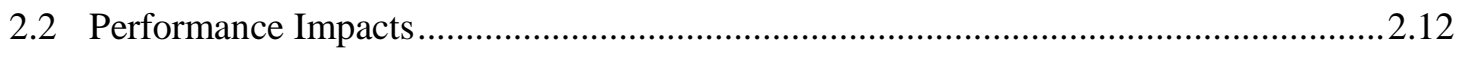

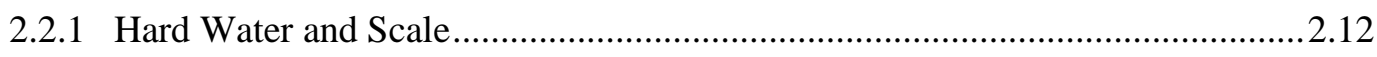

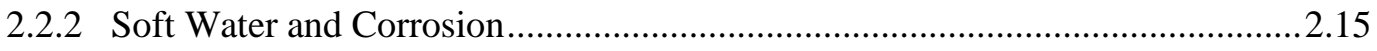

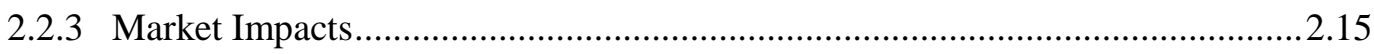

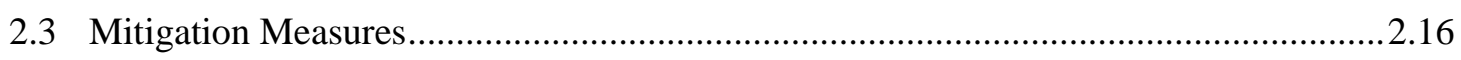

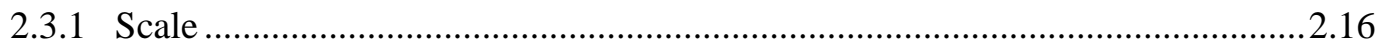

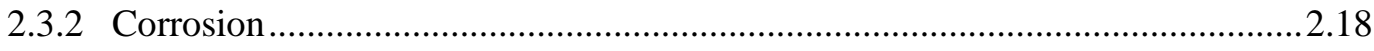

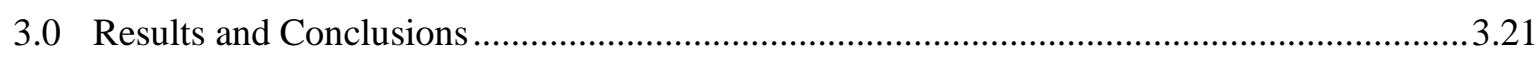

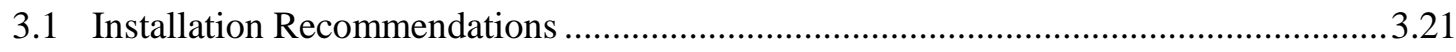

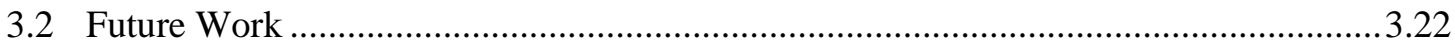

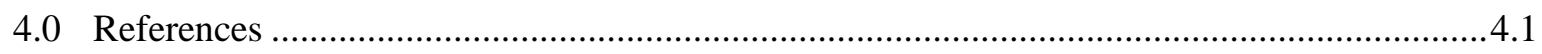




\section{Figures}

1.1 Percentage of Residential Individual Water Heaters that are Gas Storage Water Heaters, Electric Resistance Storage Water Heaters, and Tankless Water Heaters.

2.1 Baylis Curve Representing the Relationship between Alkalinity, $\mathrm{pH}$, and Stability of Water..2.5

2.2 Carbonate Water Hardness, as $\mathrm{mg} / \mathrm{L} \mathrm{CaCO}_{3}$, Measured at 344 Different Locations Across

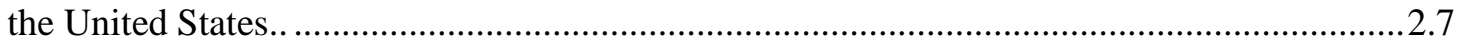

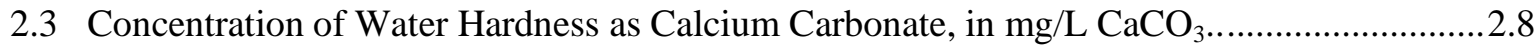

2.4 Electrochemical Corrosion Cell Formed by Heterogeneous Sections of the Pipe Wall........2.10

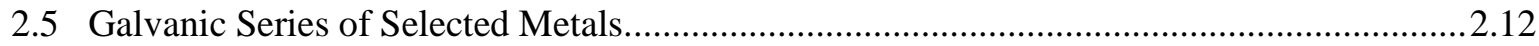

2.6 Predicted Efficiency of Gas Storage Water Heaters Operating on Soft Water and Various Levels of Hard Water from $85 \mathrm{mg} / \mathrm{L} \mathrm{CaCO}_{3}$ to $512 \mathrm{mg} / \mathrm{L} \mathrm{CaCO}_{3}$ over 10 Years with an Assumed 50 gallons per Day Hot Water Draw Volume.....................................................2.14

2.7 Percentage of Total Water Loss Claims Attributed to Each Failure Mechanism: Leak in Water Heater or Burst Tank, Unknown, Supply Line Failure, Valve Malfunction, or Other..2.16

\section{Tables}

S.1. Summary of Impacts and Mitigation Measures for Effects of Hard Water and Soft Water on

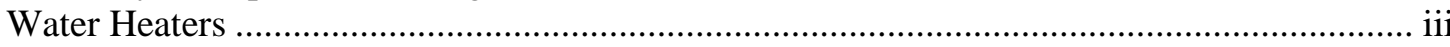

3.1. Summary of Impacts and Mitigation Measures for Effects of Hard and Soft Water on Water Heaters 


\subsection{Introduction}

\subsection{Background}

In the United States, improvements in building energy efficiency are widely acknowledged as one of the most effective ways to address a myriad of energy-related issues, from carbon pollution caused by coal-fired power plants to the rising cost of energy and the impact on household utility bills (Granade et al. 2009). Energy use in residential homes has increased over the past several decades and now accounts for 22 percent of total energy use in the United States (EIA 2012). Water heating comprises 17.7 percent of residential energy use and, as such, is often one of the measures considered for replacement or upgrade to improve residential energy efficiency.

This report will focus on individual residential water heaters, which are found in 97 percent of residential homes across the United States (as opposed to centralized systems, more typical for multifamily situations) (EIA 2012). Of these 110.6 million residential water heaters, 23.4 are gas and 45.6 are electric, as shown in Figure 1.1 below. Tank-type water heaters represent the majority of existing installations, with only 2.7 percent of existing water heaters being tankless (EIA 2012). However, the installation of tankless water heaters as an efficient replacement for gas storage water heaters is increasing, and tankless water heaters now represent approximately 5 percent of annual sales (400,000 units per year) (Parker 2011).

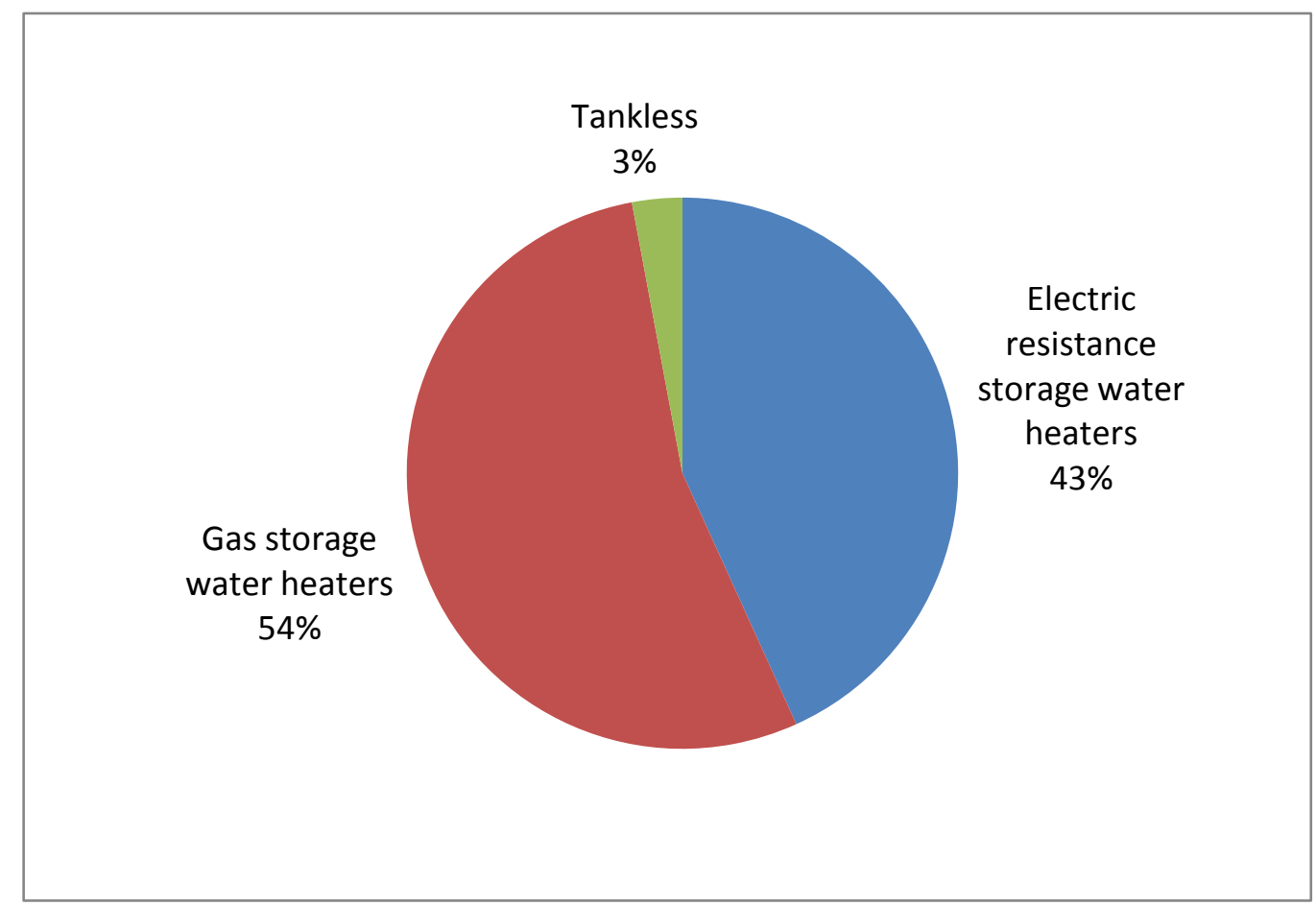

Figure 1.1. Percentage of Residential Individual Water Heaters that are Gas Storage Water Heaters, Electric Resistance Storage Water Heaters, and Tankless Water Heaters. Source: EIA 2012.

Today, many efficient water heating options are available for every fuel type, from electric and gas to more unconventional fuel types such as propane, solar, and fuel oil. The best water heating option for a given household will depend on a number of factors, including average daily hot water use (total gallons 
per day), hot water draw patterns (close together or spread out), the hot water distribution system (compact or distributed), installation constraints (such as space, electrical service, or venting accommodations), and fuel-type availability and cost. Resources for appropriate hot water heater selection based on these factors are available from several sources, including the following:

- the U.S. Department of Energy's energysavers.gov website ${ }^{1}$

- the U.S. Environmental Protection Agency's Energy Star Program website ${ }^{2}$ and

- the American Council for an Energy Efficient Economy (ACEEE). ${ }^{3}$

Recent research by Hoeschele et al. (2012) on behalf of the U.S. Department of Energy's Building America program also provides a good summary of these factors and incorporates the latest research regarding water heater efficiency, and the information will not be repeated here.

Whether gas or electric, storage or tankless, more efficient water heaters are generally more expensive than conventional water heating technologies. For example, if replacing an electric resistance water heater, a heat pump water heater is often the most efficient alternative and can save up to 62 percent over a typical efficiency electric resistance storage water heater, ${ }^{4}$ but also costs about three times as much. ${ }^{5}$ However, the savings in energy use, and thus utility bills, can recoup the additional up-front investment and make an efficient water heater a good investment over time in most situations, although the specific payback period for a given installation will vary widely. Still, a more efficient water heater can be a wise economic, as well as environmental, choice if the water heater will at least break even over the course of the water heater's life, meaning the payback period for the incremental cost is equal to or shorter than the life of the water heater.

Therefore, the expected lifetime of a water heater is also an important factor influencing appropriate water heater selection and should be considered, along with water use characteristics, fuel availability and cost, and specific home characteristics. Water heater life is generally 8 to 20 years, with the variance based on a number of factors including water heater type, water quality, and maintenance practices (EPA 2013a; DOE 2013; Ragan et al. 1996). Research has shown that local water quality is the primary cause of premature failure of water heaters (Weingarten and Weingarten 1992). Although essential to water heater life, the impact of water quality on water heater efficiency and resulting appropriate water heater selection is not considered in typical national resources, such as those available from the energysavers.gov, the Energy Star Program, or ACEEE. One reason for this may be that, since water quality and maintenance practices are so variable and complex, it is very difficult to provide standardized guidance. However, this topic of the impact of water quality on a water heater's lifetime is necessary to

\footnotetext{
${ }^{1}$ http://energy.gov/energysaver/articles/selecting-new-water-heater; http://energy.gov/articles/new-infographic-andprojects-keep-your-energy-bills-out-hot-water resistance water heater (Energy Factor, $\mathrm{EF}=0.90)$ versus a heat pump water heater $(\mathrm{EF}=2.4)$.

${ }^{5}$ Based on comparison of a 50-gal. GE 4500-watt double element 240-volt electric water heater with a 12 -year warranty at approximately $\$ 400$ and a comparable 50-gal. GE GeoSpring hybrid heat pump water heater with 10 year warranty at $\$ 1,200$.
} 
address when investing in more efficient residential water heating equipment, to ensure consumers, utilities, and the nation achieve the energy savings expected over the lifetime of the product.

\subsection{Report Contents and Organization}

This report presents a survey of the popular and scientific literature regarding municipal water quality and its impact on residential water heaters. The report covers the fundamentals of scale buildup and corrosion in water heaters, the impact of those phenomena on residential water heater performance and longevity, and steps that can be taken in the design and maintenance of equipment to prevent scale and corrosion from negatively impacting long-term residential water heater performance. In Section 3.0, the key findings are summarized and recommendations for water heater installation and maintenance are suggested to maintain efficient operation and increase equipment life, thus increasing savings potential from the appliance. Opportunities for future work are also discussed. 


\subsection{Findings from the Literature}

To determine the current technical knowledge regarding the impact of water quality on the performance of residential water heaters, researchers at Pacific Northwest National Laboratory performed a review of the scientific and popular literature. The results of that review are summarized in the following sections. Notably, the academic literature lacked a significant number of publications on this topic. Much more information, particularly application-based maintenance practices and recommendations, are available in the popular literature, but these sources are not peer reviewed. Therefore, to help ensure that the non-peer reviewed information presented has a degree of reliability and consensus in the relevant trades, only the findings appearing in at least three unique sources are included in this literature review.

\subsection{Water Chemistry Fundamentals}

Water quality impacts the performance of water heating equipment either due to soft water (i.e., corrosive water or aggressive water) or due to hard water (i.e., scale-forming water), which are on opposite ends of the water quality spectrum. Soft water will rust and eat away at ferrous (iron-containing) components in the water heater resulting in leaks and premature failure, while hard water will have the propensity to precipitate mineral deposits on any surfaces and build up sediment in the bottom of the tank, which can decrease efficiency of the water heater as well as impact lifetime and increase maintenance requirements (ASHRAE 2011b; Weingarten and Weingarten 1992).

The following sections describe the fundamental chemical characteristics of water, the typical water chemistry that is found across the United States, and the how differences in water quality contribute to scale formation and corrosion.

\subsubsection{Water Hardness and Alkalinity}

Two main terms describe water quality with regard to its propensity to produce scale or corrosion in water distribution systems or equipment — carbonate hardness and alkalinity. Water treatment professionals use many other terms to describe different chemical or biological characteristics of water that are important for water treatment, but these are outside the scope of this document (Metcalf \& Eddy 2003).

Total water hardness is called alkalinity and is a measure of mineral content in the water. Alkalinity has two primary components, carbonate hardness and non-carbonate hardness. Carbonate hardness is a measure of the concentration of carbonate $\left(\mathrm{CO}_{3}{ }^{-}\right)$and bicarbonate $\left(\mathrm{HCO}_{3}{ }^{-}\right)$salts of calcium $(\mathrm{Ca})$ and magnesium $(\mathrm{Mg})$ measured in terms of its most common constituent, calcium carbonate $\left(\mathrm{CaCO}_{3}\right.$, commonly known as lime). Similar to the measurement of greenhouse gases, which are often presented in terms of carbon dioxide equivalence, several mineral ions may contribute to the carbonate hardness of water, but the overall carbonate hardness is presented as if all of the hardness is due to $\mathrm{CaCO}_{3}$. Noncarbonate hardness is a measure of calcium and magnesium salts of other than carbonate and bicarbonate, such as calcium sulfate $\left(\mathrm{CaSO}_{4}\right)$ or magnesium chloride $\left(\mathrm{MgCl}_{2}\right)$ (MRWA 2009). 
Alkalinity is also a measure of how easily the $\mathrm{pH}$ of the water can be changed. Chemically, it represents the presence of hydroxides $\left(\mathrm{OH}^{-}\right)$, carbonates, and bicarbonates of ionic compounds such as calcium and magnesium. Thus, high alkalinity, which is typically associated with high levels of $\mathrm{CaCO}_{3}$ in municipal water supplies, is also associated with significant scaling (Metcalf \& Eddy 2003). Water with high alkalinity can be scale-forming (i.e., have the propensity to precipitate $\mathrm{CaCO}_{3}$ ) even at relatively low $\mathrm{pH}$. Conversely, waters with low alkalinity have little buffering capacity to deal with excess hydrogen ions and will quickly become acidic and corrosive.

The relationship between water stability, $\mathrm{pH}$, and alkalinity is visually represented in a graph known as the Baylis Curve, shown in Figure 2.1. The terms "hard water" and "soft water," as applied in plain language, describe the two opposing scale-forming and corrosive regions of this chart, respectively.

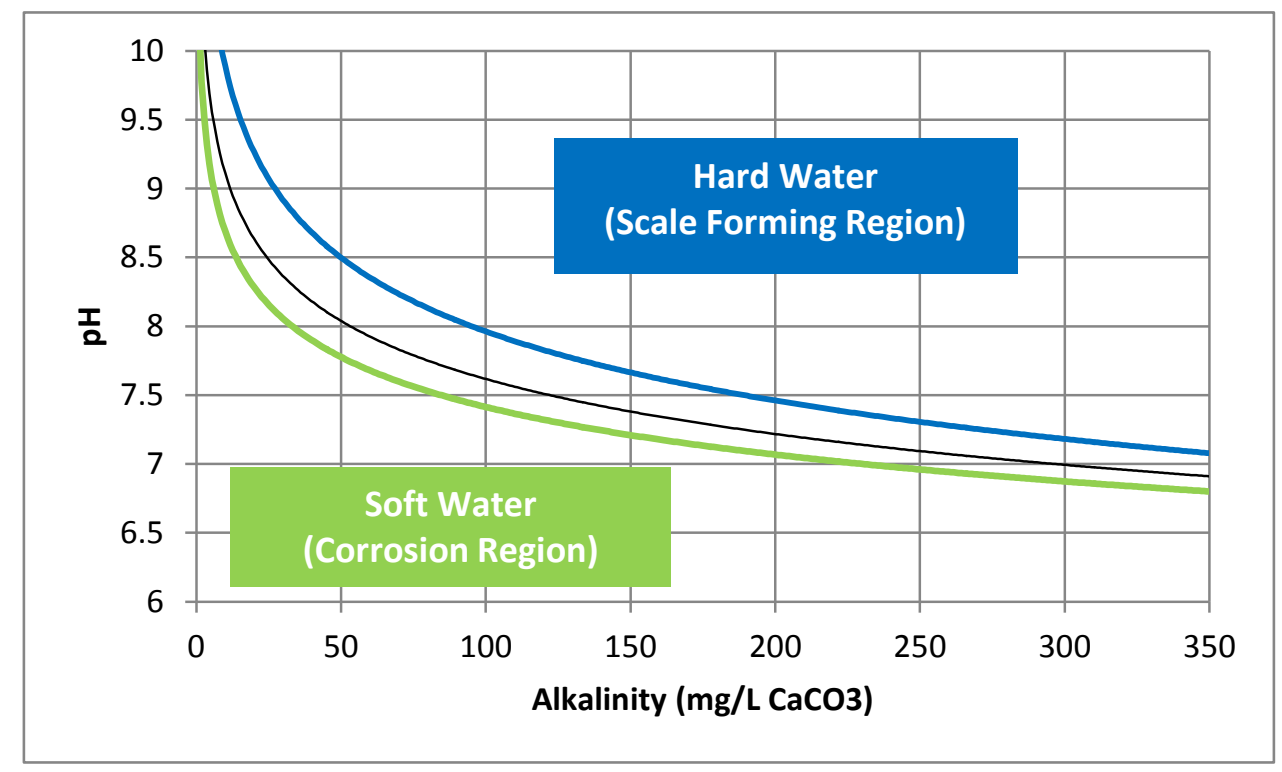

Figure 2.1. Baylis Curve Representing the Relationship between Alkalinity, pH, and Stability of Water. Source: Mountain Empire Community College 2013.

Clearly, these defined hard water and soft water categories can comprise a range of water chemistries that may vary more within a category than between categories in some cases. Nonetheless, the accepted categorization into hard and soft water is helpful in terms of describing the propensity of water to be either corrosive or scale-forming. Based on the water characteristics that are most commonly found across the United States, some generalizations regarding hard and soft water can be made. Hard water typically refers to water with high levels of carbonate hardness, the most common constituents of which are $\mathrm{CaCO}_{3}$ and $\mathrm{MgCO}_{3}$. Hard water is also typically basic (high $\mathrm{pH}$ ) and highly alkaline. Conversely, soft water has little carbonate hardness, but may or may not have high non-carbonate hardness. Soft water also typically has low $\mathrm{pH}$ (acidic) and low alkalinity. These characteristics of water make it highly corrosive, due to the availability of hydrogen ions and the non-carbonate mineral content, as described in Section 2.1.4, below.

Despite this range of characteristics that describe the propensity of water to be corrosive or scaleforming, general guidelines for classification of water are typically based solely on carbonate hardness: 0 to 60 milligrams per liter as calcium carbonate $\left(\mathrm{mg} / \mathrm{L} \mathrm{CaCO}_{3}\right)$ is classified as soft; 61 to $120 \mathrm{mg} / \mathrm{L}$ $\mathrm{CaCO}_{3}$ as moderately hard; 121 to $180 \mathrm{mg} / \mathrm{L} \mathrm{CaCO}_{3}$ as hard; and more than $180 \mathrm{mg} / \mathrm{L} \mathrm{CaCO}{ }_{3}$ as very 
hard. Water quality professionals employ a number of other theoretical and empirical indicators to describe the corrosivity or scale-forming nature of water that account for other factors in addition to carbonate hardness (Ozair 2012), but practice has shown that a simple measure of carbonate hardness is well correlated with the propensity of water to produce scale or be corrosive in most cases and is straightforward to apply.

Some previous reports have discussed water quality as it relates to residential appliance performance in terms of salinity or total dissolved solids (Ragan et al. 1996; Lohman et al. 1988; Anderson and Kleinman 1978). Total dissolved solids (TDS) is a term that describes all the organic and inorganic substances smaller than 2 micrometers dissolved or suspended in a liquid (Metcalf \& Eddy 2003). Salinity is a component of TDS and describes all inorganic ions that are dissolved in solution (Metcalf \& Eddy 2003). While it is appropriate to describe the mineral or salt content of water, it is not a useful metric to differentiate corrosive or scale-forming properties because different salts contribute to these two outcomes. To reach actionable conclusions that can help improve water heater performance and longevity, it is important to differentiate the hard and soft water and study their respective impacts on appliance performance.

\subsubsection{Water Quality in the United States}

Dissolved mineral salts (e.g., calcium and magnesium ions that cause water hardness) accumulate naturally in the water supply as water flows over and through the soil (Hem 1989). The concentration of these mineral ions is also influenced by human activity, such as irrigation, which increases evaporation and transpiration (Ragan et al. 1996). The TDS is generally limited to $500 \mathrm{mg} / \mathrm{L}$ or less of total mineral content in most public water supplies (EPA 2013b). As the major constituent of TDS, water hardness is thus similarly restricted. However, values measured in water supplies across the United States can range from 0 to over 3,000 mg/L CaCO 3 (Briggs and Ficke 1977; Ragan et al. 1996; Moor et al. 2006S). Figure 2.2 indicates that almost 75 percent of homes have water that is classified as between moderately hard and very hard, while another study determined that 80 to 85 percent of U.S. homes have hard water (Konigsberg 2011). 


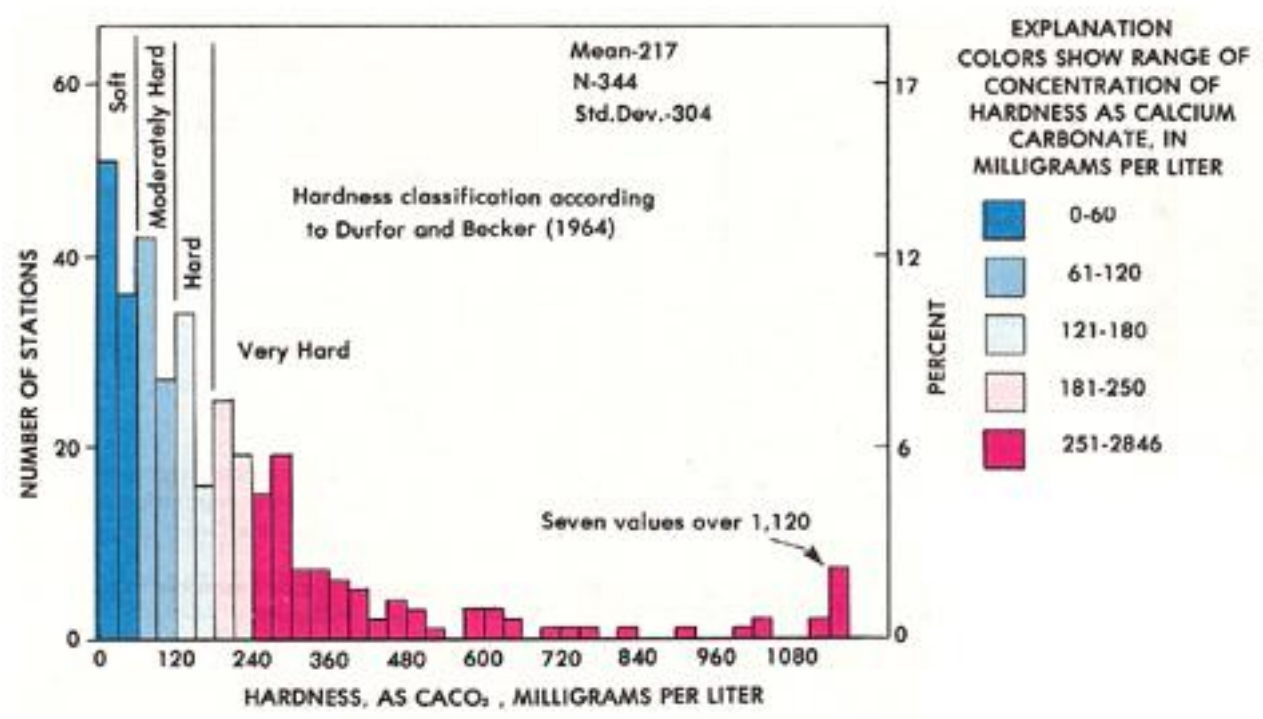

Figure 2.2. Carbonate Water Hardness, as $\mathrm{mg} / \mathrm{L} \mathrm{CaCO}_{3}$, Measured at 344 Different Locations Across the United States. Source: Briggs and Ficke 1977.

Patterns of hardness in the United States are shown on the map in Figure 2.3. The softest waters are typically found in parts of New England, the South Atlantic-Gulf States, the coastal Pacific Northwest, and Hawaii. Moderately hard waters are common in Alaska and Tennessee, in the Great Lakes region, and the inland Pacific Northwest. Hard and very hard waters were found sporadically in most of the regions throughout the country, while the hardest waters (greater than 1,000 mg/L) were measured most commonly in streams in Texas, New Mexico, Kansas, Arizona, and southern California (Briggs and Ficke 1977). 


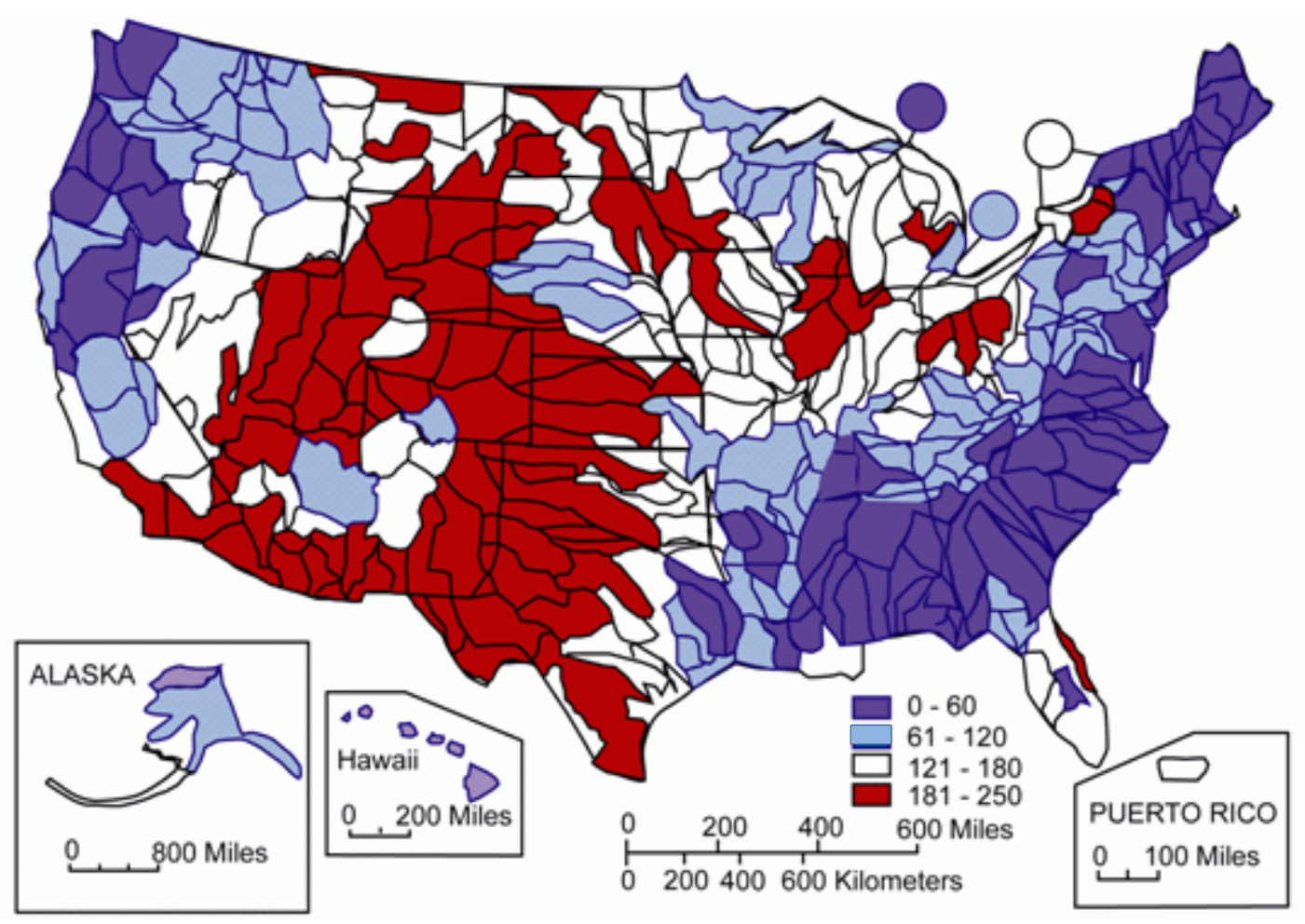

Figure 2.3. Concentration of Water Hardness as Calcium Carbonate, in $\mathrm{mg} / \mathrm{L} \mathrm{CaCO}_{3}$. Source: Briggs and Ficke 1977.

Current assessments (USGS 2013) support the data in the map from 1975, as water hardness in ground water is relatively stable and generally does not change over time.

When water hardness is over $140 \mathrm{mg} / \mathrm{L}$, water softening or other water treatment is often recommended (ASHRAE 2011b). As this represents a majority of locations in the United States, water softening is understandably becoming more ubiquitous in many regions.

Naturally soft water is defined as water with a lack of hardness, or a reduced concentration of calcium and magnesium ions ( $<60 \mathrm{mg} / \mathrm{L}$ ). Naturally soft water may have low mineral content in general (i.e., low carbonate hardness and low non-carbonate hardness), or may have high non-carbonate hardness, typically in the form of silicate, chlorate, and sulfate compounds (MRWA 2009). Water softeners, however, work by exchanging soluble sodium ions for the insoluble calcium and magnesium ions. This process is called ion exchange and is performed by a substance called zeolite. The zeolite is precharged with sodium ions, that attract the calcium and magnesium ions, and exchanges them with sodium. Periodically, the softener is recharged with sodium by running salt (sodium chloride) through the zeolite resin bed. Sodium reduces the hardness of the water, but it does not reduce the conductivity of the water. This softened water will have the same dissolved mineral content as the previously hard water it was treating, resulting in excessive conductivity in the water, which will accelerate corrosion. In addition, if the resin bed of the softener is not properly rinsed after regenerating the resin, residual salt will get into the heater. This will increase the conductivity of the water and result in even more aggressive corrosion. Water softeners accelerate anode consumption because they eliminate the formation of scale in the water heater tank, which can be protective, as discussed in Section 2.1.4. 
The way all these constituents and indices work together and impact appliance life can be quite complex. It depends on their relative ratios, the concentrations of other organic and inorganic substances in the water, temperature, and other factors. Sections 2.1.3 and 2.1.4 provide a general description of how these characteristics typically influence scale and corrosion in residential water heaters.

\subsubsection{Scale}

Scaling and sedimentation occur when the water becomes saturated with minerals contributing to carbonate hardness, principally calcium. When the water is saturated with a mineral, if any more of that mineral is added it will precipitate out of the water as a solid. In the case of calcium, calcium precipitates as $\mathrm{CaCO}_{3}$, as shown in Equation 1:

$$
\mathrm{Ca}^{+}+\mathrm{CO}_{3}^{-} \leftrightarrow \mathrm{CaCO}_{3}(s)
$$

This precipitation is primarily a problem in water heaters and hot water piping because $\mathrm{CaCO}_{3}$ is inversely soluble, meaning it precipitates more with increasing temperature. At cooler temperatures found in cold water pipes, the existing $\mathrm{CaCO}_{3}$ may remain in solution since the water is not yet saturated. However, higher temperatures will cause $\mathrm{CaCO}_{3}$ to precipitate out of solution and cause scale and sedimentation problems in water heaters. Other issues that contribute to scale issues are high water usage and, of course, the specific water chemistry. For example, if the water has a high degree of non-carbonate hardness, such as significant concentrations of chlorate $\left(\mathrm{ClO}^{3-}\right)$ or sulfate $\left(\mathrm{SO}_{4}{ }^{2-}\right)$, this will tend to increase the solubility of calcium and decrease scale formation. In addition, high water pressure will increase scale formation, as the higher pressures will force more $\mathrm{CaCO}_{3}$ out of solution (Weingarten and Weingarten 1992).

Scaling will typically occur in hard water conditions, since the concentration of calcium ions (in the form of carbonate hardness) will be high. Also, a high $\mathrm{pH}$ is characteristic of hard water, and can further lower the solubility of calcium carbonate in water.

\subsubsection{Corrosion}

Corrosion occurs via an electrochemical reaction, similar to the operation of a battery. To complete the electrolytic corrosion cell, there must be an anode that gives up electrons, a cathode that receives the electrons, an electrically conductive connection between them that allows electrons in the form of electricity to flow from the anode to the cathode, and an electrolyte to accept electrons from the cathode, maintaining its positive charge and keeping the flow going. In the case of a water heater, typically one area of the ferrous metal tank acts as the anode and another area of the tank acts as the cathode. The tank itself is electrically conducting, connecting the anode and the cathode, and the water with its dissolved salts acts as the electrolyte, as shown in Figure 2.4. 


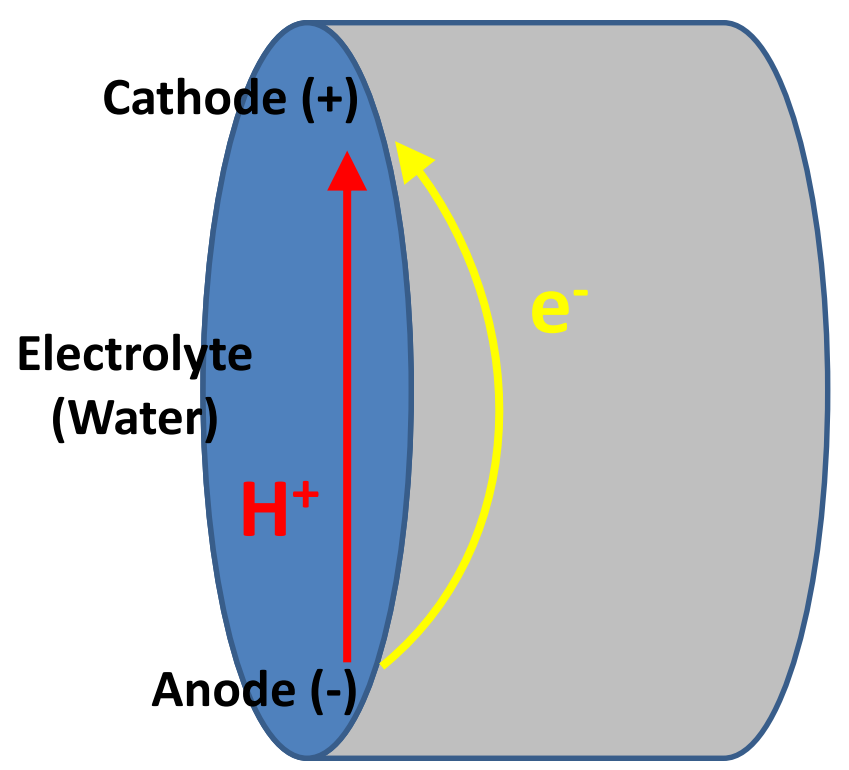

Figure 2.4. Electrochemical Corrosion Cell Formed by Heterogeneous Sections of the Pipe Wall. Because it is polarized (by the anode and the cathode), the electrolyte transfers hydrogen ions $\left(\mathrm{H}^{+}\right)$from the anode to the cathode, and the pipe serves as the electrical conductor of electrons $\left(\mathrm{e}^{-}\right)$from the anode to the cathode.

Water heater tanks are typically constructed of carbon steel, which is an alloy of iron and carbon. The iron found in steel is typically elemental $\left(\mathrm{Fe}^{0}\right)$, which is unstable and tends to oxidize at the anode, as a result of contact with an oxidizing agent, as shown in Equation 2:

$$
F e^{0} \rightarrow \mathrm{Fe}^{2+}+2 e^{-}
$$

The oxidizing agent, in most cases, is oxygen and, thus, increased oxygen concentrations will increase corrosion. The electrons produced by this reaction flow through the pipe wall to the cathode, while the ferrous iron $\left(\mathrm{Fe}^{2+}\right)$ reacts with water to produce rust (ferrous hydroxide $\left[\mathrm{Fe}(\mathrm{OH})_{2}\right]$ ) and hydrogen ions $\left(\mathrm{H}^{+}\right)$, as shown in Equation 3:

$$
\mathrm{Fe}^{2+}+\mathrm{H}_{2} \mathrm{O} \leftrightarrow \mathrm{Fe}(\mathrm{OH})_{2}+2 \mathrm{H}^{+}
$$

Ferrous hydroxide can react with water again, increasing the valence of iron and releasing additional hydrogen, to form ferric hydroxide $\left(\mathrm{Fe}(\mathrm{OH})_{3}\right)$, another form of rust (AWWA/ASCE 2012). At the cathode, the electrons combine with hydrogen ions to produce hydrogen gas, as shown in Equation 4:

$$
2 H^{+}+2 e^{-} \leftrightarrow H_{2}
$$

The type and concentration of dissolved salt(s) will determine how effective the water is as an electrolyte (i.e., how good it is at accepting and transporting hydrogen ions), which in most cases will regulate the rate and extent of corrosion.

Both hard and soft waters have the ability to act as an electrolyte provided there is sufficient mineral content. Soft water with low mineral content will not be highly conductive, and thus will limit the electrochemical reaction that produces corrosion and rust. While some water is naturally soft, the primary cause of significant equipment degradation is often due to the increased prevalence of water softeners in 
homes. This is because water softeners will be placed in homes with high mineral content and all carbonate hardness will be replaced with non-carbonate hardness, primarily sodium $\left(\mathrm{Na}^{+}\right)$ions, leading to extremely soft and electrochemically active water.

The rate of corrosion is also strongly correlated with the availability of hydrogen ions in the water. Hydrogen ions are available in the water due to the anode reaction described above, as well as naturally in acidic waters (ASHRAE 2011a). Since soft waters are naturally more acidic than hard waters, soft water has a higher propensity to lead to corrosion. The mineral content of water, which can increase the conductivity of water, will increase the rate of corrosion due to the increased availability of hydrogen ions (ASHRAE 2011a).

Produced hydrogen gas, produced in Equation 4, can coat the cathode and separate it from the water in a process called polarization, which will break the connection between the electrolyte and the cathode and slow the corrosion process. However, the presence of dissolved oxygen in the water accelerates the corrosion rate of ferrous metals by depolarizing the cathodic areas through reaction with hydrogen generated at the cathode (ASHRAE 2011a), as shown in Equation 5:

$$
2 \mathrm{H}_{2}+\mathrm{O}_{2} \leftrightarrow 2 \mathrm{H}_{2} \mathrm{O}
$$

Chlorine and nitrates are other oxidizing agents that can also react with hydrogen to depolarize the cathodic area and lead to corrosion (ASHRAE 2011a). Another constituent of water that can increase corrosion is carbon dioxide, which can react with water to form carbonic acid and lower the $\mathrm{pH}$ of water.

Temperature can also impact the propensity for corrosion in residential water heaters, since temperature increases the rate of electrochemical reactions, which increases corrosion and rust formation (ASHRAE 2011b). However, in hard water, temperature will decrease the rate of corrosion, since it will also lead to greater precipitation of $\mathrm{CaCO}_{3}$ as scale, which can also protect bare metal surfaces in the water heater (ASHRAE 2011a and b).

This electrochemical corrosion cell can be formed one of three ways: through electrolysis, oxygen concentration cells, or galvanic action. In electrolysis, spurious and ungrounded electrical currents in the hot water pipe or water tank itself can cause the flow of electrons from one section of pipe through the water heater to the ground. In this case, the ground is the cathode. An oxygen concentration cell occurs when the oxygen concentration within the tank or distribution network is heterogeneous. The portion of the water heater with low oxygen concentration becomes the anode and the portion with high oxygen concentration becomes the cathode. Oxygen concentration cells are a common type of corrosion cell in industrial and residential distribution systems, where some areas of the distribution system can remain stagnant for some time and lose their dissolved oxygen content. Oxygen concentration cells can also occur when bacteria is growing in one area of the tank, depleting the oxygen in that area (Metcalf \& Eddy 2003).

The most common type of corrosion in residential water heaters is galvanic corrosion, where differences in types of metals or even impurities in the tank itself cause corrosion cells to occur. Galvanic corrosion occurs because some metals are more active, meaning they can be oxidized and give up electrons more easily, than other metals. These metals, or areas with a higher proportion of these metals, will become the anode, and areas or pieces of equipment that are more noble (less active), will form the cathode. Figure 2.5 depicts the galvanic series, which lists metals in order of their propensity to corrode. 


\section{Anodic (Least Noble; Most Active)}

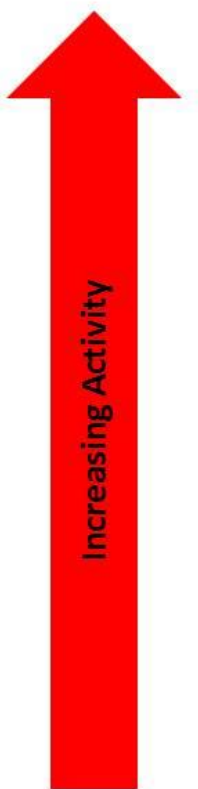

- Magnesium alloys

- Zinc

- Beryllium

- Aluminum alloys

- Cadmium

- Mild steel, wrought iron

- Cast iron, flake or ductile

- Low-alloy high-strength steel

- Tin

- Copper

- Lead-tin solder

- Tin bronze

- Nickel silver

- Lead

- Nickel 200

- Silver

- Stainless Steel (304)

- Titanium

- Graphite

- Gold

Cathodic (Most Noble; Least Active)

Figure 2.5. Galvanic Series of Selected Metals. Source: ASHRAE 2011a.

While corrosion is a complex process and dependent on many factors, in general, soft water has a higher propensity to lead to corrosion due to a higher hydrogen ion concentration and the lack of highcarbonate hardness. Also, high concentrations of non-carbonate hardness will increase corrosion in soft water. This occurs most commonly when hard water is artificially softened using water softeners.

\subsection{Performance Impacts}

Water quality can impact all water heating equipment, but the impacts of scale and corrosion will affect some more than or differently than others. With regard to tank-type water heaters, higher efficiency models like heat pump water heaters have the same requirements for incoming water quality as conventional residential storage water heaters (ASPE 2003). However, due to the higher capital cost of higher efficiency equipment, shortened life should be an important issue when considering the potential savings and cost-effectiveness of equipment.

\subsubsection{Hard Water and Scale}

The primary impact of hard water on water heater performance is the buildup of scale on heating components including heat exchangers, heating elements, or the bottom of the tank. This will decrease efficiency in some cases, but most likely will not lead to premature failure of the equipment. Lime scale buildup over time can also clog hot water pipes, the drain valve on the water heater, or the temperature and pressure relief valve on the water heater, which impact the maintenance and safety-related performance of the water heater (Weingarten and Weingarten 1992). In addition, because the sediment particles are heavier than water, once a coating has been formed on available surfaces, they tend to sink to 
the bottom and accumulate at the bottom of the tank. This accumulation of free sediment at the bottom of the tank is more likely to result in reduced equipment lifetime due to overheating elements in electric storage water heaters and overheating tank material in gas storage water heaters at the bottom underneath the sediment, which can eventually cause the water heater to fail (Weingarten and Weingarten 1992).

A study by Battelle Memorial Institute for the Water Quality Association in 2010 (the Battelle study) (Paul et al. 2010) evaluated the impact of scale formation on equipment efficiency for electric storage, gas storage, and gas tankless water heaters using an accelerating testing approach. This accelerated testing resulted in extremely high hot water supply temperatures, water use rates, and carbonate hardness levels. The study evaluated the water heaters at $150^{\circ} \mathrm{F}$ for electric storage, $160^{\circ} \mathrm{F}$ for gas storage and $140^{\circ} \mathrm{F}$ for gas tankless water heaters, and flow rates of 240, 480, and 600 gallons per day of hot water for the electric storage water heater, gas storage water heater, and gas tankless water heater, respectively. The testing was conducted using an artificially created water with hardness of approximately $444 \mathrm{mg} / \mathrm{L}$ $\mathrm{CaCO}_{3}$. Using the accelerated testing methodology, the results were extrapolated to more realistic water characteristics and use cases and led to important findings describing the impact of water hardness and scale buildup on equipment efficiency over time (Paul et al. 2010).

For electric storage water heaters, the efficiency of the water heater was maintained at the rated value until sediment reached the bottom element and buried it, causing the bottom element to overheat. Also, after such a failure, cleaning the tank and replacing the lower element were found to restore full efficiency. Thus, hard water did not appear to impact the efficiency of electric storage water heaters or the lifetime of the tank. However, the heating element on the electric water heater receiving hard water would be expected to have a shorter life (Paul et al. 2010).

For gas storage water heaters, hard water was found to decrease the efficiency of the equipment from 70.4 percent to 67.4 percent over the equivalent of 2 years, a reduction of 3 percent. These data were used to derive equations to predict the efficiency of gas storage water heaters as a function of water hardness and daily household hot water usage, as shown in Figure 2.6. 


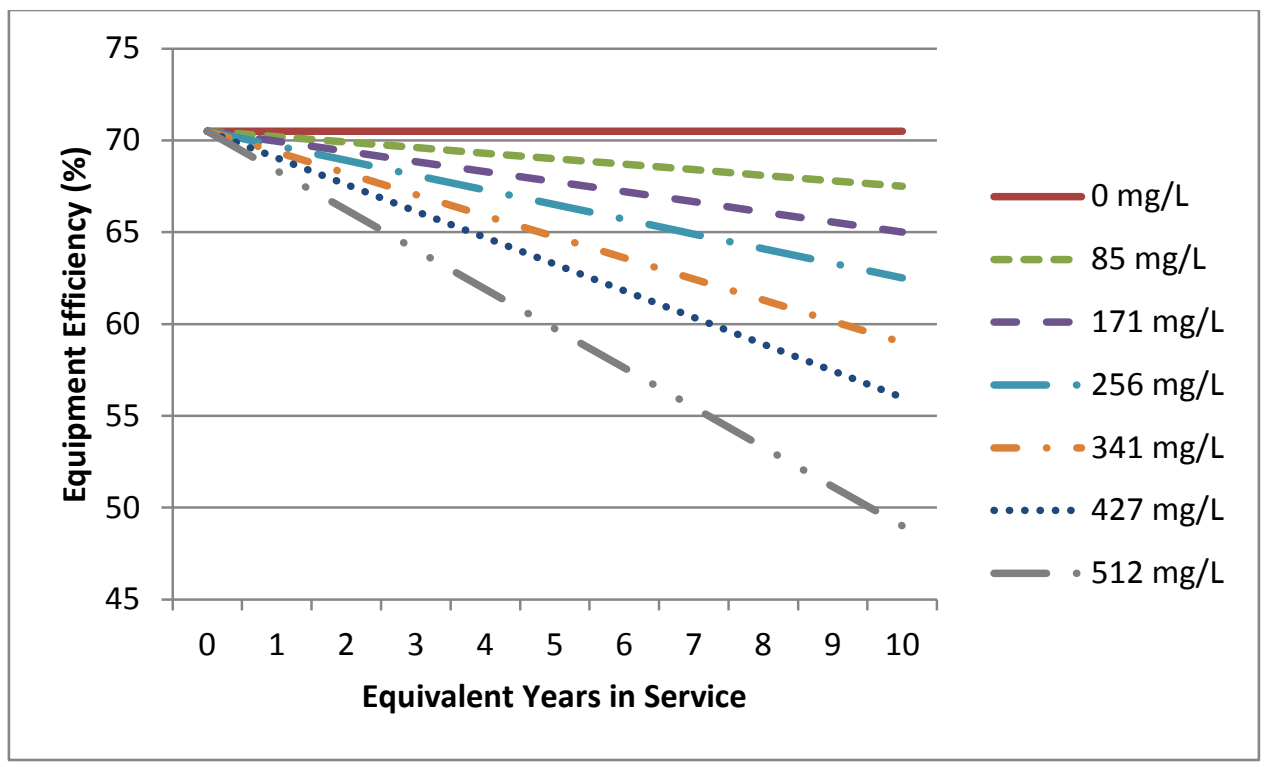

Figure 2.6. Predicted Efficiency of Gas Storage Water Heaters Operating on Soft Water $\left(0 \mathrm{mg} / \mathrm{L} \mathrm{CaCO}_{3}\right)$ and Various Levels of Hard Water from $85 \mathrm{mg} / \mathrm{L} \mathrm{CaCO}_{3}$ to $512 \mathrm{mg} / \mathrm{L} \mathrm{CaCO}_{3}$ over 10 Years with an Assumed 50 gallons per Day Hot Water Draw Volume. Source: Paul et al. 2010.

This decrease in efficiency occurs because scale and sediment buildup in gas storage water heaters can act as an insulator between the tank burner and the water. This increased insulation also causes heat to build up in the steel tank and glass lining, which can cause the glass to dissolve, degrade the steel, and expose the steel tank shell to potential corrosion (Weingarten and Weingarten 1992). While hard water is not as corrosive as soft water, for the reasons discussed in Section 2.1.4, it is still capable of causing a mild corrosive cell to occur and with such a large surface area exposed in this case, this lower activity corrosion can still lead to tank failure over time.

Another study found that a 0.06 -inch coating of lime scale on a heat exchanger in a boiler can reduce its efficiency by an average of 11 percent (ASHRAE 2011b). In both studies, efficiency decreased linearly as scale thickness increased. However, it is important to note that scale accumulates at a rate that varies depending on water characteristics, temperature, and water usage. For example, in water with a hardness of $170 \mathrm{mg} / \mathrm{L}, 0.06$ inches of lime scale could accumulate in just 4 years in a 50-gallon storage water heater with a water temperature of $140^{\circ} \mathrm{F}$ and a draw volume of 66 gallons per day. However, at $120^{\circ} \mathrm{F}$, it takes almost 30 years to generate 0.06 inches of scale under the same water draw volume. ${ }^{1}$

The Battelle study found that the efficiency of tankless gas water heaters decreased from 80 percent to 72 percent over 1.6 years, after which the tankless water heaters failed due to a clogged pressure sensor or other control device and required deliming (a maintenance process that removes scale from the water heater; see Section 2.3.1.2). The efficiency of the water heater thus was not extended to 10 years. Instead, the efficiency after regular deliming every 1.6 years was recorded. After the deliming process, the efficiency of the tankless gas water heater returned to 77 percent.

\footnotetext{
${ }^{1}$ Calculation based on data from University Bulletin No. 74, as presented in the ASHRAE 2011 HVAC Applications Handbook (ASHRAE 2011b).
} 
In addition to impact on energy efficiency, scale accumulation can have an impact on equipment longevity as well. New Mexico State University reports that by reducing and preventing mineral lime scale buildup on pipes and appliances, households could realize longer life for their appliances varying between 25 and 40 percent (Konigsberg 2011).

While too much scale can dramatically impact performance, a small amount of scale can be beneficial because it forms a barrier film on the exposed steel surfaces in the tank, such as pipe connections and weld areas. Corrosion cell tests at the Corporate Technology Center have shown steel corrosion rate drop of 33 percent with the formation of a thin (less than 1/16 in) film of scale after only three weeks in water with a hardness of $290 \mathrm{mg} / \mathrm{L} \mathrm{CaCO}_{3}$. By allowing a thin layer of scale to form on the tank, the steel would be protected, thereby increasing the life of the anode and the tank (especially if the anode rod is not regularly maintained; see Section 2.3.2.2) (AO Smith-44).

Hard water can also cause other inconveniences associated with hot water use, including the use of more soap and synthetic detergents for home laundry and washing, the generation of a film on hot water fixtures and related surfaces, and bad taste (AO Smith-13; Ragan et al. 1996)

\subsubsection{Soft Water and Corrosion}

Soft water does not appear to have a direct impact on equipment efficiency; however, soft water corrodes anode rods and will reduce the life of steel-tank storage water heaters unless proper maintenance practices are employed (Weingarten and Weingarten 1992; Paul et al. 2010). In the previously referenced Battelle study, the maintenance of efficiency over time with soft water was verified for electric and gas storage water heaters and gas tankless water heaters. However, the study did not address corrosion issues related to water softening (Paul et al. 2010). In extremely soft water, such as has been produced by a water softening system, tank lifetimes can be reduced by 50 percent or more (Weingarten and Weingarten 1992). For example, the A.O. Smith water heater manual acknowledges "artificially softened water is exceedingly corrosive because the process substitutes sodium ions for magnesium and calcium ions. The use of water softener may decrease life of water heater tank." A.O. Smith recommends inspecting the anode rod after 3 years and every year thereafter (A.O. Smith 2011). If the anode rod becomes depleted and is not replaced, it can lead to rapid tank degradation.

\subsubsection{Market Impacts}

An assessment of homeowners' insurance claims resulting from water heater failures conducted by the Insurance Institute for Business \& Home Safety (IBHS 2007) found that water heater failures are one of the top five "water loss" claims, or claims in which monetary compensation is sought as a result of water damage to furniture, equipment, or the home itself. Of the 700 water-heater-related water loss claims analyzed, 69 percent were due to leaks in the water heater or to the tank bursting, as shown in Figure 2.7. The water heater failures cost an average of $\$ 4,444$ per incident after the deductible was paid and the average age of failure was 10.7 years, but ranged from 1 to 30 years. 


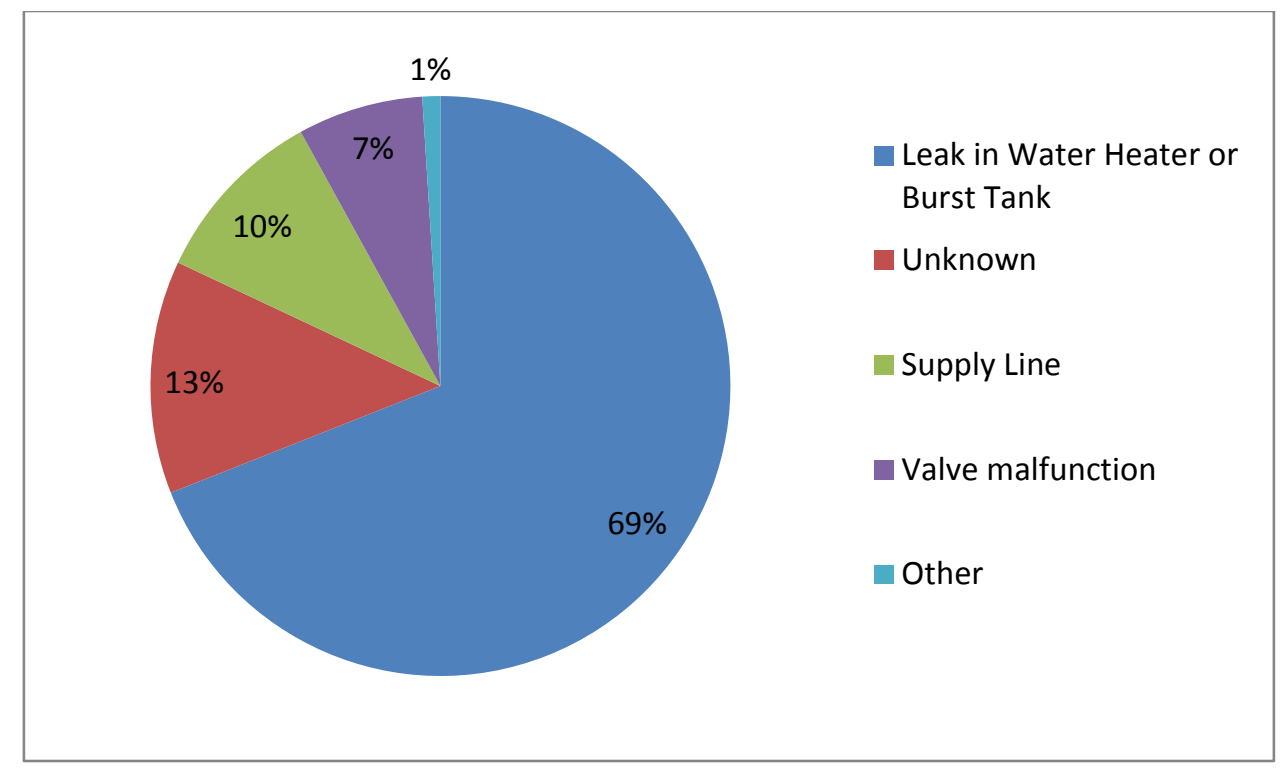

Figure 2.7. Percentage of Total Water Loss Claims Attributed to Each Failure Mechanism: Leak in Water Heater or Burst Tank, Unknown, Supply Line Failure, Valve Malfunction, or Other. Source: IBHS 2007.

Often tanks leak due to deterioration of the sacrificial anode rod and subsequent corrosion of the tank. Most homeowners are not aware of their water heater's anode rod or the fact that they are supposed to inspect it (Turriff and Bailey 2010).

\subsection{Mitigation Measures}

While both hard and soft water could cause issues for water heater performance and longevity, there are several ways these issues can be addressed in the design of new water heater tanks and through proactive maintenance activities. Both scale and corrosion increase with water usage and temperature. Therefore, easy methods to limit the risk of either and increase tank longevity are to decrease hot water use and reduce the tank temperature setpoint. However, in reducing tank temperature setpoints homeowners and builders should also be aware of potential risks of creating conditions that are conducive to bacteria growth and employ appropriate mitigation, if necessary (OSHA 2013). This will have the added benefit of saving water, energy, and money. In addition, there are some specific recommendations for different water heater types and water chemistries described in the following sections.

\subsubsection{Scale}

To address scale and sedimentation in storage and tankless water heaters, the best approach and most appropriate water heating equipment will depend on the extent of hardness in the local water supply.

\subsubsection{Tank Design}

To address long-term scaling and sediment accumulation issues in storage water heaters, some water heaters are beginning to incorporate "anti-scale" or "self-cleaning" devices in their water heaters. These two terms describe the same concept, which essentially consists of a curved dip tube that swirls the cold 
water as it enters the tank, to keep the water and sediment moving and reduce scale buildup (Weingarten and Weingarten 1992). For electric resistance water heaters, another improvement is to install longer, thicker elements that have a lower watt density and thus do not get as hot as typical high watt-density elements (Weingarten and Weingarten 1992).

\subsubsection{Maintenance}

For storage water heaters, and especially electric storage water heaters, inexpensive maintenance practices may be sufficient to address mild scaling that will occur with moderately hard to hard water conditions. The Battelle study found that for electric storage water heaters, regular flushing to prevent sediment buildup maintains efficiency for the lifetime of the equipment. For gas storage water heaters, cleaning the tank of sediment buildup was not found to restore full efficiency since the burner surface at the bottom of the tank cannot be completely cleaned; however, regular flushing and deliming to prevent sediment buildup does significantly limit the decrease in efficiency of the water heater (Paul et al. 2010).

Draining the water heater tank using the drain valve at the bottom of the tank is a simple practice that can be accomplished by homeowners with a small amount of education. Curved dip tubes, as described in Section 2.3.1.1 can also be helpful in making the tank draining process more effective (Weingarten and Weingarten 1992). Draining is recommended, conservatively every 6 months, but this frequency is probably not required in most locations. Also, flushing with acid (since lime is basic) will help remove built-up scale. Food-grade phosphoric acid, vinegar, or other commercial products will all work (Weingarten and Weingarten 1992).

The process for draining a tank is as provided in Appendix A.

\subsubsection{Water Softeners}

Another way to mitigate extremely hard water for storage and tankless water heaters is to install a water softener. For gas storage water heaters, a water softener should be a last resort unless the hard water has undesirable cosmetic characteristics, as it will add expense to the system and may decrease tank life. However, when the above tank design and maintenance approaches are not sufficiently effective, or for tankless water heaters installed in a location with hard water, where there are very few other options, a water softener may be the only viable way to improve water heater performance. Common treatments of hard water and scale include use of salt-based or chemical water softeners, filtration, and physical electronic or electromagnetic devices. A water softener is not required for electric storage water heaters (both resistant and heat pump) based on equipment performance impacts, but may be desirable to mitigate the taste and the impact of hard water on other fixtures in the home.

The chemistry of salt-based ion-exchange water softeners, which are the most common, was described previously in Section 2.1.2. Other options that will have less propensity to increase the risk of corrosion but also address the presence of carbonate hardness in water are filtration methods, such as reverse osmosis, and physical electronic or electromagnetic devices that act by manipulating mineral ions through the use of magnetism or radio frequencies introduced into the water. This process attracts charged ions and forms stable crystal nuclei that flow in the water as a suspension without settling on surfaces. By crystallizing inherent ions, this also decreases the level of saturation of the water, which causes existing scale deposits to dissolve into the water. However, such electromagnetic approaches are 
more expensive than the more conventional ion-exchange water softeners and have shown mixed effectiveness when independently evaluated (Krauter et al. 1996; Kozic and Lipus 2003).

\subsubsection{Corrosion}

To address corrosion in storage and tankless water heaters, the best approach and most appropriate water heating equipment will depend on the degree of hardness in the local water supply.

\subsubsection{Tank Design}

The first and most common approach to addressing corrosion is to use noncorrosive materials as much as possible. Manufacturers of storage water heaters typically still use carbon steel tanks for cost reasons, but almost all tanks now contain a glass lining to help protect the tank from corrosion. The glass is non-polarizable and, thus, will not corrode. Manufacturers could also consider using tanks of alternative, nonferrous materials (ASHRAE 2011b). For example, one manufacturer of electric resistance water heaters is now constructing tanks completely out of plastic, which will not be impacted by corrosive water. ${ }^{1}$ This is typically more expensive, but the cost may be recovered in locations where extremely soft water is likely to be present, such as where the water supply is artificially softened.

Similarly, tankless water heaters are constructed of less galvanically active metals to protect them from corrosion. This is because tankless water heaters cannot employ an anode rod to protect against corrosion. In addition, tankless water heaters require significantly less material than tanked water heaters, making the additional expense of using more expensive and less active metals more feasible.

Specifically, copper and stainless steel appear to be the most common materials of construction for tankless water heaters. ${ }^{2}$ Because tankless water heaters heat water on demand, the water in the lines and the heat exchanger is only hot for a short time. As both scale and corrosion increase with temperature, decreased temperature dramatically lowers the rates of both. (Weingarten and Weingarten 1992). The authors note that they were not able to locate information specific to tankless water heaters in the literature.

However, use of non-ferrous materials cannot always provide full protection from corrosion. For glass-lined storage water heaters, the glass lining may have imperfections and small gaps due to the way the tanks are manufactured. Fittings where pipes, elements, or other components enter the tank are especially prone to corrosion due to the difficulty of covering these junctions with a protective coating of glass or other material and the small surface area. Also, the glass lining can acquire imperfections over time due to the transportation process (rough handling may cause cracks in the glass lining) or during use (thermal expansion of the tank may cause the glass to fracture in places) (Weingarten and Weingarten 1992). Because the glass lining is inherently imperfect, and to incorporate redundant protection into water heaters, almost all manufacturers also include an anode rod in the design of storage water heaters.

\footnotetext{
${ }^{1}$ The Rheem Marathon water heater employs a seamless, blow-molded, polybutene tank that is impervious to rust and corrosion.

${ }^{2}$ Several sources stated that tankless water heaters had a recognized lower risk of corrosion, and the listed metals were found in several tankless water heater specification documents. However, the materials themselves are the only protection mechanism against corrosion and verification of how well the method works was not found in the literature.
} 
An anode rod can be a very effective strategy for controlling corrosion, but requires proper maintenance (see Section 2.3.2.2 below). Anode rods work by leveraging the galvanic scale (see Figure 2.5). As described in Section 2.1.4, metals on the anodic end of the galvanic scale will corrode in the presence of metals that are closer to the cathodic end of the galvanic scale, because they are more active and more readily give up electrons to the more stable metal at the cathode. Thus, anode rods are typically made out of very active metals, high on the galvanic scale shown in Figure 2.5; magnesium, aluminum, and aluminum/zinc are the most common. The anode rod then serves as the anode for the electrochemical cell, for both the tank and the fittings, sacrificing electrons to any other exposed metal. The anode rod is sacrificial and over time will dissolve through electrochemical action (Weingarten and Weingarten 1992).

Magnesium is the most prevalent material used for anode rod fabrication; but, aluminum and aluminum/zinc anodes are also used. Aluminum/zinc anode rods are typically 92 percent aluminum and 7 percent zinc, with 1 percent or less of trace metals. Aluminum and aluminum/zinc anodes are typically used if less current is needed for less aggressive soft water and should not be used if water is being intentionally softened, as they may not provide enough current to reverse the strong corrosion cell that occurs in extremely soft water (Schuyler and Weingarten 2011).

A permanent and maintenance-free alternative to the sacrificial anode is a powered anode, which also works well, but is more expensive. Unlike sacrificial anodes, powered anodes are not consumed. They reverse the corrosion cell's normal current flow by supplying a stronger current of opposite polarity directly to the anode (ASHRAE 2011a). Like a sacrificial anode, this turns the steel tank into the cathode and protects it from corrosion, but can do so indefinitely as long as the powered anode is supplied with electricity to create the artificial reversing current. A powered anode is also referred to as an "impressedcurrent" protection in industrial water treatment processes (ASHRAE 2011).

The chemical reactions that occur at the anode rod are similar to those given in Equations 2-5 above when the steel tank served as the anode. As such, the reaction also produces hydrogen gas. This typically is not a problem in most water supplies. However, some water supplies have sulfur-reducing bacteria, called desulfovibrio, that will consume any sulfites present in the water and any accumulated sediment to produce sulfide in the water. The sulfide will combine with hydrogen gas generated by the electrochemical cell and create hydrogen sulfide gas $\left(\mathrm{H}_{2} \mathrm{~S}\right)$. The primary concern with $\mathrm{H}_{2} \mathrm{~S}$ gas is its odor; $\mathrm{H}_{2} \mathrm{~S}$ gas has an unmistakable rotten egg smell at concentrations as low as 1 to $2 \mathrm{ppm}$ (Rheem).

To address this problem, decreasing water temperature, decreasing sediment buildup (a source of sulfites for the bacteria), chlorination, or replacing the anode rod can help mitigate the issue. (Note: the anode rod should not be removed, as this will severely limit the life of the water heater). However, if a magnesium anode rod is installed, replacing it with a less active aluminum or aluminum/zinc anode rod will reduce the anodic reaction, providing slightly less protection, but also limiting the amount of hydrogen gas that is formed, and thus the availability of hydrogen to produce $\mathrm{H}_{2} \mathrm{~S}$ (Schuyler and Weingarten 2011). It is also worth noting that the desulfovibrio bacteria is anaerobic, meaning it thrives in oxygen-depleted environments, like the sediment that has collected at the bottom of the water heater (Weingarten and Weingarten 1992) or hot water, since the solubility of oxygen in water decreases with increasing temperature (ASHRAE 2011a). Another way to address the bacterial problem is to treat the water with chlorine, although this will increase the oxidizing power of the water and, thus increase corrosion activity (ASHRAE 2011a). 
In addition to an unpleasant odor, the creation of $\mathrm{H}_{2} \mathrm{~S}$ will also increase the acidity of the water, further increasing its corrosivity. This will initiate a damaging cycle, as increased corrosion causes the anode rod to be consumed more quickly, which produces more hydrogen for bacteria to use to produce $\mathrm{H}_{2} \mathrm{~S}$ gas. Powered anode rods do not react with bacteria as the anodic metal varieties do, and thus do not cause odor (Schuyler and Weingarten 2011).

Another, albeit less common, form of the electrochemical corrosion cell is caused by electrolysis. This occurs when the tank or related piping will fail due to corrosion caused by spurious, ungrounded currents that travel through the water heater as the electrical current is transmitted to ground. To mitigate corrosion caused by stray electrical currents in the pipes (i.e., electrolysis), it is important to connect the hot and cold pipes above the water heater with \#6 copper wire and make sure the cold water pipe is connected to the outdoor ground rod (Weingarten and Weingarten 1992).

\subsubsection{Maintenance}

Sacrificial anode rods are very effective protection against corrosion and will maintain water heater performance and lifetime if the anode rod is inspected frequently and changed when necessary. Sacrificial anodes should be inspected after 3 to 4 years, and annually thereafter, for customers with normal water quality (Weingarten and Weingarten 1992). In locations with especially active soft water or artificially softened water, anode inspection is recommended annually, at first, as intentional water softening will lead to more rapid anode consumption. Many manufacturers conservatively recommend annual anode rod inspection (IBHS 2007).

The anode rode should be replaced if more than 6 inches of the bare core wire is visible, if the anode rod has corroded to less than half its original diameter, or if the anode rod exhibits heavy pitting or splitting down its length. Another, less common, way the anode rod can fail is passivation, which occurs when $\mathrm{CaCO}_{3}$ scale covers the anode and limits the protection provided by the anode. Passivation of the anode is indicative of high carbonate hardness water, which may indicate that corrosion is less of an issue. However, water with high carbonate hardness is not necessarily completely noncorrosive, so some anode protection can still add incremental life to the water heater in some cases. If any of these situations are observed, it indicates that the anode rod requires replacement with a similar sacrificial anode or with a powered anode (Weingarten and Weingarten 1992).

For extremely corrosive water, a second anode rod can be installed in some water heaters (one in the anode rod port on top of the water heater and one combination anode in the hot water outlet) for additional protection and to increase the time between anode rod replacements (Weingarten and Weingarten 1992). 


\subsection{Conclusions and Recommendations}

When determining the appropriate selection and application of water heating equipment, especially when determining the cost-effectiveness of more expensive, high efficiency equipment options, the lifetime of equipment is very important. Increasing the lifetime of water heaters can improve the costeffectiveness and increase the savings achieved, which can offset the initial investment in an energyefficient water heater. Accumulation of scale and corrosion can decrease the lifetime and impact performance of water heating equipment; in fact, studies have shown corrosion to decrease equipment life by more than half if not properly mitigated (Weingarten and Weingarten 1992). In addition accumulation of scale will impact the efficiency of gas storage and tankless water heaters (Paul et al. 2010).

In Section 3.1, selection and installation recommendations are provided for electric storage water heaters, gas storage water heaters, and gas tankless water heaters based on information in the literature. Section 3.2 identifies gaps in the current body of knowledge surrounding the impact of water quality on residential water heating equipment and recommends opportunities for future investigation.

\subsection{Installation and Maintenance Recommendations}

As summarized in Table 3.1, based on a review of the available scientific and popular literature, several mitigation approaches were identified for traditional electric resistance and gas storage water heaters.

First, research shows that excessively soft water, especially water that is artificially softened from salt-based water softeners, can reduce the life of tanked water heaters by 50 percent or more (Weingarten and Weingarten 1992). Therefore, artificial water softeners should only be employed in extreme cases of water hardness and non-salt based water softeners should be considered. If artificial water softeners are employed, annual inspection of the anode rod or installation of a powered anode rod is recommended. If the sacrificial anode rod is properly maintained and replaced as necessary or a powered anode rod is installed, current research suggests that the effects of soft water on tank integrity can be minimized or eliminated.

However, scale and sediment build-up can also affect equipment efficiency and lifetime for gas tanked and tankless water heaters, reducing water heater efficiency by up to 10 percent in extreme cases (Paul et al. 2010) and reducing equipment lifetime by 25 to 40 percent (Konigsberg 2011). For cases with moderate hard water, annual tank draining (for storage water heaters), deliming, installation of a curved dip tube can be an effective means to address scale and sediment buildup. For electric storage water heaters, extremely hard water may necessitate installation of a lower density element, but since scale and sediment buildup do not adversely affect tank performance or lifetime until sediment reaches and buries the bottom element, artificial water softening is generally not recommended from an equipment maintenance perspective. However, for gas equipment, scale and sediment buildup in extremely hard water may justify installation of artificial water softening equipment and the associated maintenance costs (e.g., from anode inspection and replacement).

For tankless water heaters, current research suggests that artificial water softening may be required in most hard water conditions, since scaling has a significant impact on equipment efficiency and can reduce tank lifetime to less than 2 years in extremely hard water conditions, unless frequent and costly deliming 
processes and related manufacturer-recommended maintenance practices are employed. In addition, tankless water heaters have more inherent protection from corrosion in soft water, due to the use of less active metals as materials of construction for the heat exchanger and piping. However, as further elaborated in section 3.2, "Further Work," more research is needed on the extent of this protection and if it is sufficient in all cases.

The design and maintenance recommendations for electric and gas storage water heaters apply regardless of the equipment efficiency. However, diligent attention to the maintenance practices or more expensive design mitigation options may be warranted for higher efficiency models with higher capital cost. For example, for heat-pump electric storage water heaters it may be cost-effective to include a powered anode rod as a design option to promote longevity of the equipment, as opposed to the typical, less expensive magnesium sacrificial anode rod. Some heat pump water heater manufacturers include a powered anode in the default equipment design. A powered anode rod is more reliable because it removes the need for regular inspection of the anode rod to ensure long-term tank performance. Conversely, a sacrificial anode rod places the burden on the homeowner to perform proper maintenance and replacement of the anode rod to prevent premature failure due to corrosion. Regular anode rod inspection and replacement does not appear to be a common practice, so installing powered anodes in heat pump water heaters may be an advisable solution to support energy savings over the expected lifetime of the equipment.

In all cases, effective solutions that should prevent premature failure and degradation of efficiency for electric storage water heaters, gas storage water heaters, and tankless water heaters were identified and are summarized in Table 3.1. However, these critical maintenance practices are not being employed consistently and, as a result, water heaters are failing prematurely, which is a cost burden on homeowners and the nation. In addition, shortened water heater lifetimes limit the energy savings and costeffectiveness of new, high-efficiency technologies.

As such, the effective design and maintenance practices identified in this report should be shared with homeowners and builders to aid in choosing the most appropriate water heating technology for a given situation. It is important that water quality and long-term performance impacts are considered in costeffectiveness and life-cycle cost analyses to make sure consumers, utilities, and the nation achieve the energy savings expected over the lifetime of the product.

\subsection{Future Work}

Information is available to provide robust guidance on water heater selection and maintenance based on local water quality characteristics. However, there are several areas where additional information or tools will reinforce a robust set of recommendations for all water heater types and help disseminate best practices related to water heater selection and maintenance.

First, the available information still requires a significant amount of interpretation to determine the most appropriate solution for a particular location with specific water quality characteristics. A userfriendly tool could be devised that performs a life-cycle cost assessment accounting for local water quality characteristics, the cost of fuels in the area, the expected life of a sacrificial anode rod and cost of its replacement, the cost of a powered anode, the cost of deliming solution, the cost of a water softener, 
and any professional maintenance costs. The rate of scaling and rate of corrosion could be estimated based on available water quality information and the mitigation options weighed against one another to determine the optimal solution. This tool would assist homeowners and builders in selecting appropriate equipment and could recommend an informed maintenance schedule for that location.

Second, in cases where water softening is required, corrosive ion exchange methods are currently the only demonstrated and reliable method for treating very hard water. There is limited information available on alternative water softening methods other than ion exchange, such as the comparative performance and reliability of magnetic or electronic devices. Unbiased, third-party verification of these alternative water softening methods, along with cost analysis to determine cost-effectiveness compared to ion exchange and anode replacement, could provide useful information to homeowners and plumbing contractors when selecting and protecting water heating equipment in areas with hard water.

Third, additional information is needed on the performance of tankelss water heaters in soft water conditions to fill gaps in the body of knowledge related to the impacts of water quality of water heater performance. In addition, limited information was available in the literature on electric tankless units. Future work could sample homeowners with tankless water heaters in areas with known soft water or areas with hard water and water softeners to determine average lifetime and assess corrosion characteristics. This research will help ensure robust, research-based recommendations are available for all water heater types in all water conditions.

Finally, homeowners also play a key role in ensuring maintenance practices and design options are employed over time. To increase awareness of homeowners and builders about the impacts of water quality on water heater performance and provide strategies for maintaining long-term water heater performance in any water quality condition, the recommendations provided in this report should be shared with users via an accessible, web-based information tool such as the Building America Solution Center. Many homeowners are unaware of the maintenance their water heater requires and that a few simple steps could dramatically improve the performance of the water heater and increase its life.

As new methods of improving water heater performance and innovative technologies are developed and disseminated, it is important that necessary selection and maintenance information based on local water quality be shared to make sure that maximum energy savings and equipment life are achieved. 
Table 3.1. Summary of Impacts and Mitigation Measures for Effects of Hard and Soft Water on Water Heaters

\begin{tabular}{|c|c|c|c|c|}
\hline \multirow[b]{2}{*}{$\begin{array}{c}\text { Water Heater } \\
\text { Type }\end{array}$} & \multicolumn{2}{|r|}{ Hard Water } & \multicolumn{2}{|c|}{ Soft Water } \\
\hline & Impact & Mitigation & Impact & Mitigation \\
\hline $\begin{array}{l}\text { Electric } \\
\text { Storage }\end{array}$ & $\begin{array}{l}\underline{\text { Efficiency }}=\text { negligible } \\
\underline{\text { Lifetime }}=\text { minimal } \\
\text { until sediment covers } \\
\text { bottom element (rare). }\end{array}$ & $\begin{array}{l}\text { - Install curved dip tube } \\
\text { - Regularly (every year) drain tank } \\
\text { to remove sediment and delime as } \\
\text { necessary } \\
\text { - Reduce tank temp and reduce } \\
\text { water use } \\
\text { - Install lower watt density } \\
\text { elements }\end{array}$ & $\begin{array}{l}\text { Efficiency }=\text { none. } \\
\text { Lifetime }=\text { Up to } 50-60 \% \\
\text { reduction in expected } \\
\text { lifetime, based on water } \\
\text { quality and maintenance } \\
\text { practices for steel, glass- } \\
\text { lined tanks }\end{array}$ & $\begin{array}{l}\text { - Purchase a tank made of } \\
\text { noncorroding material } \\
\text { - Inspect anode rod every 1-2 } \\
\text { years and replace as necessary } \\
\text { or use powered anode } \\
\text { - Consider installing second } \\
\text { anode rod } \\
\text { - Reduce tank temp and reduce } \\
\text { water use }\end{array}$ \\
\hline Gas Storage & $\begin{array}{l}\text { Efficiency }=\text { negligible } \\
\text { Lifetime }=\text { minimal } \\
\text { until sediment covers } \\
\text { bottom element (rare). }\end{array}$ & $\begin{array}{l}\text { - Install curved dip tube } \\
\text { - Regularly (every year) drain tank } \\
\text { to remove sediment and delime as } \\
\text { necessary } \\
\text { - Reduce tank temp and reduce } \\
\text { water use } \\
\text { - Soften water (with appropriate } \\
\text { anode protection) }\end{array}$ & $\begin{array}{l}\text { Efficiency }=\text { none } \\
\underline{\text { Lifetime }}=\text { minimal until } \\
\text { sediment covers bottom } \\
\text { element (rare) }\end{array}$ & $\begin{array}{l}\text { - Purchase a tank made of } \\
\text { noncorroding material } \\
\text { - Inspect anode rod every 1-2 } \\
\text { years and replace as necessary } \\
\text { or use powered anode } \\
\text { - Consider installing second } \\
\text { anode rod } \\
\text { - Reduce tank temp and reduce } \\
\text { water use }\end{array}$ \\
\hline $\begin{array}{l}\text { Gas and } \\
\text { Electric } \\
\text { Tankless }\end{array}$ & $\begin{array}{l}\text { Efficiency }=\text { negligible } \\
\underline{\text { Lifetime }}=\text { minimal } \\
\text { until sediment covers } \\
\text { bottom element (rare). }\end{array}$ & $\begin{array}{l}\text { - Regularly delime equipment as } \\
\text { recommended by manufacturer } \\
\text { - Reduce temp setpoint and reduce } \\
\text { water use } \\
\text { - Soften water }\end{array}$ & $\begin{array}{l}\text { Efficiency }=\text { none } \\
\underline{\text { Lifetime }}=\text { reduced due to } \\
\text { use of less active metals in } \\
\text { materials of construction* }\end{array}$ & - Unknown \\
\hline
\end{tabular}




\subsection{References}

10 CFR 430.32(d). 2012. "Energy Conservation Program for Consumer Products. Energy and Water Conservation Standards. Water Heaters." Code of Federal Regulations, U.S. Department of Energy. Accessed October 11, 2013, at http://www.gpo.gov/fdsys/pkg/CFR-2012-title10-vol3/pdf/CFR-2012title10-vol3-sec430-32.pdf.

ACEEE - American Council for an Energy Efficient Economy. 2013. Water Heating. American Council for an Energy Efficient Economy. Washington, D.C. Available at:

http://aceee.org/consumer/water-heating. Last updated September 30, 2013. Last accessed October 6, 2013.

Anderson, JC and AP Kleinman. 1978. Salinity Management Options for the Colorado River: Damage Estimates and Control Program Inputs. Utah Water Research Laboratory, Logan, Utah.

A.O. Smith-13. Technical Bulletin 13: Mineral Build-up.. A.O. Smith, Ashland, Tennessee. Undated. Available at: http://www.hotwater.com/lit/bulletin/bulletin13.pdf)

A.O. Smith-44. Technical Bulletin 44: Water Softeners.. A.O. Smith, Ashland, Tennessee. Undated. Available at: http://www.hotwater.com/lit/bulletin/bulletin44.pdf.

A.O. Smith. 2011. Instruction Manual: Installation, Operation, \& Maintenance. A.O. Smith, Ashland, Tennessee. Available at: http://www.hotwater.com/lit/im/res gas/320898-000.pdf.

ASPE - Association of Plumbing Engineers. 2003. Domestic Water Heating Design Manual. 21: Heat Pump Water Heaters. American Society of Plumbing Engineers, Rosemont, Illinois.

ASHRAE. 2011a. “49: Water Treatment.” HVAC Applications. American Society of Heating, Refrigeration, and Air-Conditioning Engineers, Atlanta, Georgia.

ASHRAE. 2011b. "50: Service Water Heating.” HVAC Applications. American Society of Heating, Refrigeration, and Air-Conditioning Engineers. Atlanta, Georgia.

Briggs, JC, and JF Ficke. 1977. Quality of Rivers of the United States, 1975 Water Year -- Based on the National Stream Quality Accounting Network (NASQAN). U.S. Geological Survey, Open-File Report 78200. Washington, D.C. Available at: http://pubs.er.usgs.gov/usgspubs/ofr/ofr78200.

AWWA/ASCE - American Water Works Association and American Society of Civil Engineers. 2012. Water Treatment Plant Design. 5th Ed. McGraw-Hill Book Company. New York.

DOE - U.S. Department of Energy. 2013. New Infographic and Projects to Keep Your Energy Bills Out of Hot Water Energysavers.gov; U.S. Department of Energy. Washington, D.C. Available at: http://energy.gov/articles/new-infographic-and-projects-keep-your-energy-bills-out-hot-water. Last updated September 30, 2013. Last accessed October 6, 2013.

EIA - U.S. Energy Information Administration. 2012. 2009 Residential Energy Consumption Survey. U.S. Energy Information Administration, Washington, D.C. Available at:

http://www.eia.gov/consumption/residential/. 
EPA - U.S. Environmental Protection Agency. 2013a. ENERGY STAR Qualified Water Heaters Which Type is Right for You? ENERGY STAR; U.S. Environmental Protection Agency. Washington, D.C. Available at: http://www.energystar.gov/index.cfm?c=water_heat.pr_help_me. Last updated September 30, 2013. Last accessed October 6, 2013.

EPA - U.S. Environmental Protection Agency. 2013b. "Secondary Drinking Water Regulations: Guidance for Nuisance Chemicals." Water: Drinking Water Contaminants. U.S. Environmental Protection Agency. Washington, D.C. Available at: http://water.epa.gov/drink/contaminants/secondarystandards.cfm. Last updated May 31, 2013. Last accessed October 6, 2013.

Granade, HC, J Creyts, A Derkach, P Farese, S Nyquist and K Ostrawski. 2009. Unlocking Energy Efficiency in the U.S. Economy. McKinsey \& Company; Global Energy and Materials. Washington, D.C. Available at:

http://www.mckinsey.com/client service/electric power and natural gas/latest thinking/ /media/20446 3A4D27A419BA8D05A6C280A97DC.ashx.

Hem, JD. 1989. Study and Interpretation of the Chemical Characteristics of Natural Water. U.S. Geological Survey of Water-Supply Paper 2254. Washington, D.C.

Hoeschele, M; D Spring; A German; J Staller and Y Zhang. 2012. Strategy Guideline: Proper Water Heater Selection. U.S. Department of Energy Building America Program. Washington D.C. Available at: http://www.nrel.gov/docs/fy12osti/55074.pdf.

IBHS - Institute for Business \& Home Safety. 2007. At the Forefront: Emerging Issues in Property Loss, Water Heater Failure Risks. Insurance Institute for Business \& Home Safety. Richburg, South Carolina. Available at: http://www.disastersafety.org/studies-reports/water-heater-failure-risks/.

Konigsberg, P. 2011. "The True Costs of Limescale." Water Technology. Available at: http://www.watertechonline.com/articles/the-true-costs-of-limescale.

Kozic V and LC Lipus. 2003. "Magnetic water treatment for a less tenacious scale.” Journal of Chemical Information and Computer Sciences 43 (6): 1815-9.

Krauter PW, JE Harrar, SP Orloff and SM Bahowick. 1996. Test of a Magnetic Device for Amelioration of Scale Formation at Treatment Facility D. OSTI 567404. Lawrence Livermore National Laboratory. Livermore, California. Available at: http://www.osti.gov/scitech/biblio/567404.

Lohman, LC, JG Milliken, and WS Dorn. 1988. Estimating Economic Impacts of Salinity of the Colorado River. U.S. Department of the Interior, Bureau of Land Reclamation. Washington, D.C.

Metcalf \& Eddy, Inc. 2003. Wastewater Engineering (4 ${ }^{\text {th }}$ Ed). McGraw-Hill Book Company. New York.

MRWA - Minnesota Rural Water Association. 2009. "Hardness." Minnesota Water Works Operations Manual. Minnesota Rural Water Association. Elbow Lake, Minnesota. Available at: http://www.mrwa.com/OPIntro.htm. 
Moor, S, E Cuartas, B Alwattar and J Lane. 2006. "How Much Calcium Is in Your Drinking Water? A Survey of Calcium Concentrations in Bottled and Tap Water and Their Significance for Medical Treatment and Drug Administration." Hospital for Special Surgery Journal (HSSJ) 2:130-135.

Mountain Empire Community College. 2013. "Corrosion." Water/Wastewater Distance Learning Website. Available at: http://water.me.vccs.edu/concepts/corrosioncauses.html.

OSHA - Occupational Safety \& Health Administration. 2013. "Section II:C-1. Domestic Hot-Water Systems." Legionnaires' Disease. Occupational Safety \& Health Administration. Washington, D.C. Available at: https://www.osha.gov/dts/osta/otm/legionnaires/hotwater.html. Last accessed November 5, 2013.

Ozair G. 2012. "An Overview of Calcium Carbonate Saturation Indices as a Criterion to Protect Desalinated Water Transmission Lines from Deterioration." Nature and Pollution Technology (11)2:203-212.

Parker M. 2011. Water Heater Shipments Projections. Presentation at ACEEE Hot Water Forum. A.O. Smith. Ashland, Tennessee. Available at: http://www.aceee.org/files/pdf/conferences/hwf/2011/Plenary\%20-\%20Mike\%20Parker.pdf.

Paul DD, VV Gadkari, DP Evers, ME Goshe and DA Thornton. 2010. Final Report: Study on Benefits of Removal of Water Hardness (Calcium and Magnesium Ions) From a Water Supply. Battelle Memorial Institute, Columbus, Ohio. Available at:

http://www.wqa.org/pdf/external uploads/Battelle Final Report.pdf?CFID=302378\&CFTOKEN=65082 $\underline{265 .}$.

Ragan G, C Makela, and R Young. 1996. "Use of Accelerated Testing Methods With Survey Data: How Water Quality Affects Appliance Life." Family and Consumer Sciences Research Journal 24(3):254271.

Rheem. "Technical Service Bulletin: Smelly Water and the Rotten Egg Odor." Rheem/Ruud. Undated. Accessed September 26, 2013 at: http://waterheatertimer.org/pdf/Water-heater-Sulfer-Smell.pdf.

Schuyler R and L Weingarten. 2011. "Replacing anodes, getting rid of odor." Water Technology. Available at: http://www.watertechonline.com/articles/replacing-anodes-getting-rid-of-odor.

Turriff DR and MN Bailey. 2010. "Hot Water Heater Failures - Assessing a Common Residential Risk." MEA Forensic; Claims Canada. Richmond, British Columbia. Available at: http://www.meaforensic.com/Portals/45635/docs/mea_water_heaters_claims_canada.pdf.

USGS - U.S. Geological Survey. 2013. Water Hardness and Alkalinity. U.S. Geological Survey WaterQuality Information. Available at: http://water.usgs.gov/owq/hardness-alkalinity.html. Last updated August 21, 2013. Last accessed September 30, 2013.

Weingarten L and S Weingarten. 1992. "The Water Heater Workbook. www.larryweingarten.com, Monterey, California. 



\section{Appendix A}

\section{Process for Draining a Water Heater Tank}





\section{Appendix A}

\section{Process for Draining a Water Heater Tank}

1 Turn off the source of power to the heater. For an electric heater, this may involve removing the fuse or turning off the circuit. For a gas-powered water heater, turn off the burner or set to "pilot."

2 Turn off the water and relieve pressure on the system. Shut off the valve for the cold water source and open all or several of the hot water faucets in fixtures connected to the heater to relieve pressure on the system.

3 Drain the tank. Attach a garden hose to the drain bib near the bottom of the tank or place a bucket under the drain. Open the drain valve on the water heater. Shut it off and empty the bucket as needed. Return the bucket and continue draining the water heater tank until it is empty.

4 Clean out any clogs. If the water refuses to drain or is draining slowly, carefully probe the sediments built up around the drain with an object that fits through the drain hole, such as a narrow brush or piece of coiled wire.

5 Restore the water flow to the tank. Let it flush through the heater until the draining water shows no discoloration or trace of sediment.

6 Close the water heater's drain valve. If deliming also, add the selected acid (vinegar works well) and fill the tank one-third to halfway. Let it set for several hours or overnight. Then flush the acid solution out of the system and go on to Step 7.

7 Refill the tank and restore power. Open the cold water inflow valve and refill the tank. The open hot water faucets will produce water when the water heater is full. When they do, shut off the hot water faucets and restore power to the water heater. 


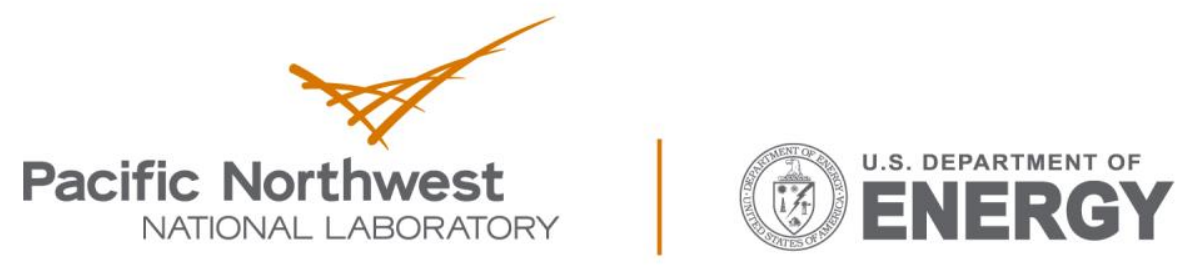

Proudly Operated by Battelle Since 1965

902 Battelle Boulevard

P.O. Box 999

Richland, WA 99352

1-888-375-PNNL (7665)

www.pnnl.gov 